MICHAEL L. WACHTER

University of Pennsylvania

\title{
Primary and Secondary Labor Markets: A Critique of the Dual Approach
}

OVER THE PAST several years, a number of economists have developed what is called the "dual labor market" theory. Much of this work has been empirical or descriptive in nature and has been heavily oriented towards the specific policy problem of poverty and unemployment. ${ }^{1}$ The popularity of this theory has been fed by claims that it is nonneoclassical if not antineoclassical in substance, and that it could solve certain empirical puzzles

Note: I am grateful to the National Science Foundation and the National Institutes of Health for research support. The paper was written while I was on leave at Princeton University. Valuable comments were provided by Bennett Harrison, Paul J. Taubman, Susan M. Wachter, members of the Brookings panel, and members of the Princeton and Minnesota labor workshops. I also wish to thank James Orr, Gail Moskowitz, and Linda Martin for research assistance.

1. By the dual literature, I refer to the theories set forth in the work of, among others, Peter Doeringer, Michael Piore, Lester C. Thurow, Bennett Harrison, Barry F. Bluestone, Thomas Vietorisz, Howard M. Wachtel, and Charles Betsey. This is not meant to be a complete list. Not all of the work of these individuals falls exclusively into the dual literature classification. Some overlaps more traditional approaches, while some intersects with the radical paradigm. No attempt is made here to analyze the radical school, since its theoretical framework is quite distinct from the dual model. The distinction between the dual and radical camps, as well as the appropriate categorization of the various authors, parallels David M. Gordon, Theories of Poverty and Underemployment: Orthodox, Radical, and Dual Labor Market Perspectives (Heath, 1972). 
in the poverty and unemployment data that purportedly could not be explained by the neoclassical literature.

Although research on the dual labor market has attracted considerable attention, from both economists and policymakers, ${ }^{2}$ it has not been subjected to a detailed critique by economists who have not themselves taken the approach. ${ }^{3}$ Since the model has been developed by a number of authors, each of whom has presented a unique view of the dual framework, its interpretation is subject to some confusion. In addition, the dualists have concentrated on policy issues and have made little attempt to develop an overall framework for their analysis. The purpose of this paper is to attempt to integrate the disparate strands in this literature and to provide a critique of the dualist model. Following the dualists' interests, I have concentrated on policy-related problems rather than on methodological concerns.

The model of the dual labor market rests on three general hypotheses. First, the economy contains two sectors, a primary high-wage and a secondary low-wage sector, and the behavior of firms and individuals in the two require different theoretical explanations. Second, the important distinction for economic analysis is that between good and bad jobs rather than between skilled and unskilled workers. Third, workers confined to the secondary sector develop a pattern of job instability, moving frequently among jobs and into and out of unemployment and labor force participation.

Good jobs make up the primary sector of the dual economy, while bad jobs and the workers frozen out of the primary sector compose the secondary sector. In that sector jobs are sufficiently plentiful to employ all workers, but they are low paying, unstable, and generally unattractive. Workers are barred from the primary sector not so much by their own lack of human capital as by institutional restraints (such as discrimination) and by a simple

2. For example, to an extent unusual for a new set of hypotheses, it has gained a hearing from congressional committees. Its views on labor market behavior also provide the background for the employment and earnings inadequacy index, a new measure of labor problems offered as an alternative to the traditional unemployment measures and developed by government and private research economists. See Sar A. Levitan and Robert Taggart III, Employment and Earnings Inadequacy: A New Social Indicator (Johns Hopkins University Press, 1974).

3. Exceptions are the radical critique by Gordon, Theories of Poverty, pp. 43-52, and an analysis of certain aspects of the dual program by Robert E. Hall, "Prospects for Shifting the Phillips Curve through Manpower Policy," Brookings Papers on Economic Activity (3:1971), pp. 659-701. (This publication is referred to hereafter as BPEA, followed by the date.) Currently, Glen G. Cain is developing a critique of the dual and radical models from a neoclassical perspective. 
lack of good jobs. As such, workers in the secondary sector suffer from underemployment.

In analyzing the primary market, the dualists have concentrated on describing the "internal labor market," a construct that was originally sketched in the labor relations and industrial engineering literature of the 1950s. Their major hypothesis is that efficiency plays only a small part in the internal labor market; thus wage rates and jobs are distributed among primary workers according to such factors as custom rather than productivity. A second, related, proposition is that the number of primary or skilled jobs is not responsive to the relative availability of skilled workers. This has important, nonneoclassical, implications since it suggests that expansion in human capital may not lead to an upgrading of the job structure. These issues are analyzed in the next section.

The dual approach to the secondary sector revolves around four interrelated hypotheses: First, it is useful to dichotomize the economy into a primary and a secondary sector. Second, the wage and employment mechanisms in the secondary sector are distinct from those in the primary sector. Third, economic mobility between these two sectors is sharply limited, and hence workers in the secondary sector are essentially trapped there. Finally, the secondary sector is marked by pervasive underemployment because workers who could be trained for skilled jobs at no more than the usual cost are confined to unskilled jobs. In this sense emphasis should be placed on good versus bad jobs rather than skilled versus unskilled workers. These issues are explored in the third section.

The dual literature has concentrated on the nature of unemployment among secondary workers when the economy is prosperous, arguing that it is structural. But it presents a different view of structural unemployment from that developed in the early 1960s. According to the dualists, there are more than enough jobs in the secondary market, but they are "bad" jobs, characterized by poverty wages and dead ends. Hence, the dualists hypothesize, the cause of the deep unemployment in the secondary sector is high turnover resulting from a lack of incentive for workers or employers to maintain stable employment relationships. The dualist model of unemployment is discussed in the fourth section.

The policy prescription of creating better jobs or more "good" jobs is the central conclusion of the dual theory, and conflicts with standard neoclassical analysis. According to the dualists, the main problem with the labor market is the scarcity of good jobs, and hence, the crucial assignment for public policy is to create more good ones, in either the private or the 
public sector. ${ }^{4}$ Policy tools, alone or in combination, are legislating higher wages and better working conditions in the private sector and increasing public service employment specifically for secondary workers. The dualists also hypothesize that aggregate demand policies and manpower training cannot solve the underemployment problem. They argue that expansion of aggregate demand will serve only to create more bad jobs as the primary sector subcontracts work to the secondary sector. Manpower training, as they see it, is simply unnecessary. Secondary workers have the human capital they need-what they lack is access to good jobs. The policy implications of these dualist arguments are analyzed in the fifth section.

A general hypothesis threading through the literature is that the dual model is nonneoclassical. Moreover, dual theorists and radical theorists seem to agree that, while their paradigms overlap, they are largely distinct. The dual literature makes little use of the mainstays of the radical modelfor example, the class struggle and exploitation. The nonneoclassical claims of the various dual hypotheses are analyzed as they arise in the various sections.

As is always the case, these hypotheses can be stated and interpreted more or less rigidly. A special feature of the literature on the dual labor market is its strong policy orientation; and that orientation may help to explain the tendency of many dualists to take a relatively rigid theoretical line. Although this paper discusses a strict dual model, it also assesses the validity and novelty of the model when some of the strong assumptions are relaxed.

My view of the neoclassical labor market model is broader than the textbook competitive case. ${ }^{5}$ Institutional arrangements do exist in the real world, and have been acknowledged even by the mainstays of applied

4. The dualists do support manpower training and aggregate demand policies geared to lowering unemployment, but they insist that they are not sufficient to solve the structural problems. In any case, the novel element in the dual approach is its stress on creating more good jobs.

5. Although the issue of whether the dual literature is nonneoclassical is definitional, there is an important underlying question. In arguing that their results are nonneoclassical, the dualists take a further step and assume that no traditional model can incorporate their institutional or empirical findings. This assumption allows them to jump to their policy conclusions on the basis of an incomplete model of the labor market. I ask the opposite question: Can a new institutional or empirical development be incorporated into a broadened neoclassical framework? In that way, one can make policy statements that, although not startling, rest on a more complete view of the economic system. The conclusions, however, are different from those proposed by the dualists. 
neoclassical economics, the Chicago school. Indeed, the classic text on the empirical impact of labor unions has been written by $\mathrm{H}$. Gregg Lewis and the initial seminal work on discrimination was done by Gary Becker. ${ }^{6}$ At times, the dual literature seems to imply that the very existence of institutions such as labor unions or of discrimination makes the neoclassical model irrelevant. To be sure, some orthodox economists argue that such institutions have relatively small effects; for example, while they recognize that unions may raise wages, they insist that the effect is muted by the tendency of firms to raise their hiring requirements in response. In any case, that is not the position taken here, nor is it a necessary feature of neoclassicism.

I use the neoclassical label as a shorthand definition for that group of economists who, while recognizing the impact of institutions and viewing the economy as built of industrial and demographic segments, integrate these elements into labor market models in which maximizing behavior and traditional price theory are central. ${ }^{7}$ The lineage begins with the classical economists, Adam Smith and John Stuart Mill, and includes a diverse group of modern economists who have been concerned with labor market problems, such as John T. Dunlop, R. A. Gordon, Charles C. Holt, and Albert Rees. ${ }^{8}$ My terminology thus contrasts with that of others, who de-

6. H. G. Lewis, Unionism and Relative Wages in the United States: An Empirical Study (University of Chicago Press, 1963); Gary S. Becker, The Economics of Discrimination (University of Chicago Press, 1957).

7. Most labor market analysis over the past several years has utilized one of three modes of structuring the model. The continuous-queue model is perhaps the most widely utilized in theoretical work, especially in the search literature, and posits the existence of a continuum of workers and firms.

In empirical work, segmented models tend to dominate. The effect of segmentation is to interrupt the continuum. Studies that place firms and workers in discrete geographical, industrial, occupational, skill, race, sex, or age categories essentially are utilizing segmented markets. The advantage of segmented markets over a continuous queue is that the former saves on scarce or unavailable data. Segmented models are most useful where the discrete segments are actually important dividing markers.

Two-sector models have appeared in both theoretical and applied work. In this research the dichotomization is almost invariably viewed as an abstraction from a multisector world. One distinguishing feature of the dual literature is its serious attempt to describe the labor market as a two-sector market. Although some segmentation is permitted within each of the two sectors, the boundaries between the two are quite rigid.

8. For example, Adam Smith, The Wealth of Nations (Modern Library, 1937), especially Book 1, Chap. 8, "Of the Wages of Labour," and Chap. 10, "Of Wages and Profit in the different Employments of Labour and Stock"; and John Stuart Mill, Principles of Political Economy (Appleton, 1877). The roots in antiquity of the dual and radical models 
fine the neoclassical position as focusing on competitive labor market models that are undisturbed by institutional realities. Although this paper is aimed at the dualist literature, I hope to make clear that that model implicitly provides a useful critique of the competitive labor market model. I will distinguish among (1) the "dual" model, (2) the competitive model that rules out institutional barriers and industrial and demographic segmentation and in which human capital considerations are dominant, and (3) the neoclassical model as defined above.

\section{The Primary Sector}

The central hypothesis of the dual model is the existence of two sectors of the economy; a high-wage primary and a low-wage secondary sector. The former is composed of industries or firms-or, more precisely, of their components-that have internal labor markets.

\section{STRUCTURE}

It is generally agreed, by both dualists and neoclassical economists, that the internal labor market consists of a set of structured employment relationships within a firm, embodying a set of rules, formal (as in unionized firms) or informal, that govern each job and their interrelationships. ${ }^{9}$ These

are stressed by Sherwin Rosen in his book review of Gordon's Theories of Poverty and Underemployment in Journal of Political Economy, Vol. 82 (March/April 1974), pp. 43739. The current modeling of segmented markets in a neoclassical model is carried furthest by Charles C. Holt and his associates at the Urban Institute. See, for example, Charles C. Holt and others, The Unemployment-Inflation Dilemma: A Manpower Solution (Urban Institute, 1971).

9. The workings of the internal labor market were studied intensively in the late 1940 s and 1950s by researchers in industrial relations and labor economics. Although much of the literature was concerned with the impact of industrial unions, a new phenomenon at the time, the issues involving structured labor markets were not new and had been studied in a nonunion context as well. See, for example, Clark Kerr, "The Balkanization of Labor Markets," in Labor Mobility and Economic Opportunity, Essays by E. Wight Bakke and others (Technology Press of MIT and Wiley, 1954); and John T. Dunlop, "The Task of Contemporary Wage Theory," in George W. Taylor and Frank C. Pierson (eds.), New Concepts in Wage Determination (McGraw-Hill, 1957). A theoretical foundation for the study of internal markets was provided by Gary S. Becker's classic study, Human Capital (Columbia University Press for the National Bureau of Economic 
rules, for example, cover job content and wages, opportunities on the promotion ladder, and grievance procedures. A complex employment relationship has developed primarily because of the elaboration of tasks that are specific to a job and hence require specific training, often acquired on the job. Because of these institutional realities the competitive model's description of a labor market based on demand and supply for each job does not apply. Most jobs are unique and lack an external market. Hence, the labor market is far from a bourse. New workers are used principally to fill entry jobs, while most higher-level positions are filled by promotion from within. Ports of entry are likely to be open to the unskilled, and to those who have the lowest semiskills, craft-oriented skills, and certain managerial and staff talents. As a consequence of specific training, workers already in a firm have an advantage over outsiders, and in a sense, enjoy a degree of monopoly power over their jobs. At the same time, the firm's potential control over the worker also grows, since the worker's specific training is most worthwhile to his current employer.

The dualist interpretation of the internal labor market is open to disagreement. One general claim it makes is that, although efficiency factors are relevant to managerial decisionmaking in the internal labor market, they are not dominant. ${ }^{10}$ More specifically, they claim that productivity or a high wage adheres to the job rather than to the worker; that the wage structure is dominated not by efficiency considerations but rather by custom and habit; and that good jobs go to people who are already with the firm by methods of promotion that largely reflect institutional arrangements. Consequently, the distribution of jobs and income in the primary sector is not dictated by ability and human capital. In addition, the dualists argue that the number of jobs in the primary sector is unresponsive to the availability of good workers, and buttress that claim with the empirical finding that it is invariant with respect to the relative factor price of good workers. ${ }^{11}$ Apart from that issue, however, the dual literature contains little empirical work on the primary sector.

Research, 1964). The industrial relations and human capital literature have been pulled together by Peter B. Doeringer and Michael J. Piore, Internal Labor Markets and Manpower Analysis (Heath, 1971), to form an overall analysis of the internal labor market.

10. The dual position on the primary sector is developed largely by Doeringer and Piore, Internal Labor Markets.

11. Michael J. Piore, "The Impact of the Labor Market upon the Design and Selection of Productive Techniques within the Manufacturing Plant," Quarterly Journal of Economics, Vol. 82 (November 1968), pp. 602-20. 
The dualists do not propose any motives that substitute for efficiency. This is a serious gap in their analysis, especially given their policy orientation. It leaves them unable to predict the response of high-wage firms to various policy programs aimed at creating more "good" jobs.

I take a different approach and view the internal labor market as an efficiency-oriented institutional response to the market forces generated by idiosyncratic jobs and the technology of on-the-job training. ${ }^{12}$

The efficiency argument can be summarized in the following manner: Idiosyncratic jobs that require specific training present a pervasive problem of bilateral monopoly. An important purpose of the internal labor market is to neutralize the issue so that it does not absorb the resources of the firm to the detriment of both workers and management. Accomplishing this aim involves minimizing bargaining and turnover costs; encouraging workers to exercise their specific knowledge; and ensuring that investments of idiosyncratic types, which constitute a potential source of job monopoly, are undertaken without risk of exploitation by either side. Contrary to the dualist argument, important features of the employment relationship encourage efficiency: first, although firms attach wage rates to individual jobs and not to workers, they do so to reduce bargaining costs, and to further the proper functioning of the organizational structure; second, except for entry jobs, the firm fills jobs by promoting meritorious workers through the organizational structure as they acquire training. High-wage jobs do not make high-wage workers; rather, the internal market screens workers and places the good ones in good jobs. The differences between the dualist approach and the efficiency argument are discussed below.

\section{THE INTERNAL LABOR MARKET}

Internal wage structure. Doeringer and Piore stress the role of such factors as community wage surveys, individual merit ratings, and job evaluation schemes in determining the wages attached to particular jobs. The surveys and ratings are clearly neoclassical forces; the former measure competitive market forces in general and the latter weigh the value of the individual worker. Doeringer and Piore, however, choose to interpret the

12. The efficiency position is discussed in greater detail in Oliver E. Williamson, Michael L. Wachter, and Jeffrey E. Harris, "Understanding the Employment Relation: The Analysis of Idiosyncratic Exchange" (University of Pennsylvania, 1974; processed), forthcoming in Bell Journal of Economics and Management Science. 
job evaluation scheme as not strongly influenced by efficiency considerations. Their view is that although market forces impose lower limits on the wages in certain jobs, management has substantial discretion in setting rates. Essentially, an infinite number of equilibrium internal wage structures exist, and efficiency does not determine the one that prevails.

The efficiency approach agrees that the firm has considerable flexibility in setting its relative or internal wage structure so long as the average wage is sufficiently high to attract the necessary labor supply. The external market does impose some constraints on relative wages, because the firm hires workers in several generally distinct occupational labor markets. For example, it may hire unskilled workers to do janitorial work, semiskilled workers to operate machinery (and perhaps eventually to be promoted and trained as skilled operators), skilled craftsmen (such as electricians), clerical workers, and managerial personnel. This, however, does not force the firm's wages for entry jobs to equal those elsewhere; it requires merely that the expected discounted value of the job-earnings stream, including promotion possibilities, be high enough to attract the necessary workers. ${ }^{13}$

In general, then, the competitive market does not determine any individual wage rate within the firm (except for an entry job that is not part of a promotion ladder). Even so, firms cannot set their relative wages arbitrarily. As the literature on job evaluation schemes emphasizes, they are designed to advance intrafirm efficiency. For example, the wage structure attaches sufficient wage increases to promotions to make them sought after. Authority relationships are cemented by paying a worker more than those he supervises. As Meij summarizes, "the internal wage-structure [is] the value dimension of the organization-structure."14

13. More specifically, the workers need to find the wage attractive. Thus, a firm that had a reputation for good promotion possibilities could pay a lower entry wage. The difficulty in communicating its wage structure, as well as its promotion ladders, to a general, external labor market is an important reason why a firm tends to hire through referrals from its current workers. Established workers can transmit the complex employment relationship to potential new workers much less expensively than other advertising methods can.

14. J. L. Meij, "Wage-Structure and Organization-Structure," in J. L. Meij (ed.), Internal Wage Structure (Amsterdam: North-Holland, 1963), p. 115. Actually, much of the analysis of the dualists can be reinterpreted in an efficiency context. Piore describes the role of sociological factors in determining the interactions of workers with each other and with management. Although Piore considers his model development nonneoclassical, a more accurate statement is that these factors have not traditionally been modeled by neoclassical economists. A profit maximizer setting up an internal wage structure would do well to take into account the factors described by Michael J. Piore, 
In this context, it is important to determine whether the internal wage structure is responsive to government pressure. Could attempts to equalize incomes focus on internal differentials? Thurow and Lucas suggest a policy of altering the "sociological judgments about 'fair' wage differentials." 15 But a number of problems would limit the effectiveness of this approach. First, job evaluation schemes have the strongest impact within promotion ladders. Although a lower-skilled entry worker might eventually rise into management, the promotion ladders for blue-collar production workers and management tend to be separate. Each has its own entry jobs, drawing on distinct external labor markets. Hence, one could alter the relative wages of different grades of machine operators, but the existence of separate markets for broader categories of workers such as semiskilled workers and managers interferes with attempts by firms to alter their relative wages. Second, even within promotion ladders, job evaluation plans attempt to weigh various factors so as to promote internal efficiency. If semiskilled helpers earned only a little less than their skilled supervisors they would have little incentive to absorb the training that provides the firm with its skilled blue-collar workers. These issues are at the core of the interpretation of the internal wage structure. Internal relative wages may serve a purpose even though a perfectly competitive market does not determine each wage. ${ }^{16}$ The "sociological" factors of Piore and Thurow are essentially the "taste" variables of the efficiency model that determine the attitudes of workers toward training and the nonpecuniary aspects of jobs. Custom, inertia, and attitudes must be weighed in establishing an efficient wage structure. ${ }^{17}$

"Fragments of a 'Sociological' Theory of Wages," in American Economic Association, Papers and Proceedings of the Eighty-fifth Annual Meeting, 1972 (American Economic Review, Vol. 63, May 1973), pp. 377-84.

15. Lester C. Thurow and Robert E. B. Lucas, "The American Distribution of Income: A Structural Problem," A Study Prepared for the Use of the Joint Economic Committee, 92 Cong. 2 sess. (1972), p. 44.

16. The importance of intrafirm wage differentials in encouraging workers to accept training and promotions is stressed in the literature on wage structures in communist countries. The efficiency orientation of the internal labor market has a long tradition in this literature. For a western interpretation, see Harold Lydall, The Structure of Earnings (Oxford University Press, 1968).

17. In some cases payment by result is instituted as a direct way of providing incentives. These schemes have become somewhat less popular recently because of the cost of administering them and their disruptive effects if they are not closely managed. Demoralization can easily arise from initially successful plans as a consequence of the slow but continuous technological change that alters the structure of jobs. Promotions can serve the same purpose of providing a pecuniary advantage to superior performance on the job. 
Internal mobility. Dualists and more traditional economists agree that the internal labor markets of the high-wage sector assure that most upward mobility will be accomplished through internal promotions rather than by changing firms. The shifts among firms disproportionately involve young workers who have not yet advanced on the internal promotion ladder. Once a worker has mounted a ladder, moving to another firm becomes costly: it means losing his place on the ladder, since firms generally hire only at the entry rung.

The promotion ladder has important functions in an efficient internal labor market that are neglected by the dualists, who view promotions as dominated by seniority and by institutional and social arrangements in general. First, it serves to reward meritorious performance and to reduce turnover. Although almost all jobs carry a salary range within which raises are possible, it is necessarily limited, and hence the opportunity to promote workers to higher-ranking jobs is desirable. As Becker and others have pointed out, specifically trained workers must be paid more than their opportunity costs to other firms in order to discourage quits. As a worker moves up a promotion ladder, the gap between his opportunity wage, at the entry point of an alternative firm, and his actual wage widens.

A second advantage of promotion ladders is that workers may acquire not only specific information about their own jobs, but also specific training for higher-level jobs in the firm. Simple physical proximity, or the opportunities provided by the lines of authority within a firm to observe the job content of those higher on the ladder, abets this process. In other words, training for advancement is a joint product with the firm's output as workers perform their jobs.

Promotion ladders also provide a screening mechanism within the firm. That the performance of a worker on the job, rather than straight seniority, is important in promotions is illustrated in a recent study by the Bureau of Labor Statistics, which found that fewer than 2 percent of workers were covered in major collective bargaining agreements in which promotion was based on seniority alone. ${ }^{18}$ Ability and performance are likely to be even more dominant in the nonunion sector and in clerical and professional jobs.

Recent theoretical literature on screening has stressed that, because both workers and firms possess only imperfect information, the wage distribution will depend on the distribution of information as well as on native

18. U.S. Bureau of Labor Statistics, Major Collective Bargaining Agreements: Seniority in Promotion and Transfer Provisions, Bulletin 1425-11 (1970), p. 5. 
ability, schooling, and the like. ${ }^{19}$ The arbitrary nature of any wage distribution appears to support the spirit of the dual model. Whereas the dualists (and some of the analysts of screening) argue that multiple equilibria result from the operation of the internal labor market, I disagree. In my view, an important purpose of the internal labor market is to provide a continuous screening function. Credentials acquired elsewhere are evaluated at the hiring point; but thereafter, in a technology that requires specific and on-thejob training, an internal labor market may well be the most efficient apparatus for collecting and analyzing data on individual performance. This interpretation has three aspects: First, if screens, such as education, did not provide useful information, they would eventually be discarded. ${ }^{20}$ Second, statistical discrimination is not ruled out since employers are likely to economize on costly information. As long as errors in the hiring process can be rectified ex post, however, firms have less incentive to establish absolute entry bars. Besides the outright firing of workers who were hired in error, firms can minimize losses by halting those workers on the promotion ladder. Third, as a consequence of sequential screening in internal labor markets and reliance on a number of different tests, workers have less tendency to overinvest in order to surmount a particular barrier.

\section{THE FIRM'S WAGE RELATIVE TO EXTERNAL WAGES}

Jobs in the primary sector are good jobs in part because they pay high wages. But why do some firms pay more than the competitive wage? In the dualist model, the essence of good jobs appears to be that they offer specific training. High wages, promotion possibilities, and other desirable attributes seem to accompany this feature. In the dualist framework, however, specific training alone cannot account for the high wages. Given the dualists' characterization of the internal labor market as inefficient, their primary market firms must wield market power. One would expect a positive correlation between firms with market power and firms that utilize specific training for blue-collar workers. A large investment in specific training

19. Michael Spence, “Job Market Signaling," Quarterly Journal of Economics, Vol. 87 (August 1973), pp. 355-74; and Joseph E. Stiglitz, "Theories of Discrimination and Economic Policy," in George M. von Furstenberg and others (eds.), Patterns of Racial Discrimination, Vol. 2, Employment and Income (Heath, 1974).

20. This discussion excludes screens consciously designed to discriminate against certain types of workers. It also does not deny the possible differences between social and private returns. 
involves a large investment in human capital. Furthermore, the type of specific training that Doeringer, Piore, and others discuss is related to the use of extensive physical capital. Consequently, these firms have high fixed costs and are likely to be in concentrated industries that have product market power and are more easily unionized.

Although market power may be pervasive in the primary sector of the dualist model, this does not mean that all high-wage jobs and all jobs with specific training are associated with market power. As Hall, Okun, and Ulman - and Doeringer and Piore-have argued, firms with specifically trained workers can trade off high wages against saving in heavy turnover costs. ${ }^{21}$ Unit labor costs are unchanged so that the competitive position of the firm is not lost. Consequently, along with market power, specific training can be a source of high wages. ${ }^{22}$

\section{THE SUPPLY OF GOOD JOBS IN THE PRIMARY SECTOR}

Are good jobs scarce given the supply of good workers? The dualists seem to argue that the failure of high-wage firms to emphasize efficiency itself causes a scarcity of good jobs. The major empirical work in the dual interpretation of the primary sector claims to find support for this view. When Piore surveyed businessmen about the factors that influence their decisions on technology design, they indicated that relative factor prices for various skill categories of labor were not important. ${ }^{23}$ Given the nature of the study, this finding should not be surprising. The results, however, do not imply that the neoclassical price mechanism is not working. First, within the internal wage structure, relative wages are controlled by the firm itself and set by job evaluation schemes. Consequently, within limits, firms

21. Robert E. Hall, "Why Is the Unemployment Rate So High at Full Employment?" BPEA (3:1970), pp. 369-402; Arthur M. Okun, "Upward Mobility in a High-Pressure Economy," BPEA (1:1973), pp. 207-52; and Lloyd Ulman, "Labor Mobility and the Industrial Wage Structure in the Postwar United States," Quarterly Journal of Economics, Vol. 79 (February 1965), pp. 73-97.

22. To what extent these high wages represent a wage premium may be disputed by a strict "human capitalist." He would argue that the lifetime earnings stream of the specifically trained, properly discounted using the high-risk premium associated with specific training, equals the lifetime competitive earnings stream. Hence, the wage premium is actually a competitive return on a risky investment. See Donald O. Parsons, "Specific Human Capital: An Application to Quit Rates and Layoff Rates," Journal of Political Economy, Vol. 80 (November/December 1972), pp. 1120-43.

23. Piore, "Design and Selection." 
should not be constrained by relative wages in their decisionmaking. Second, even if firms looked to the external market, relative factor prices for broadly categorized labor skills change very slowly over time. Hence, factor prices should have a noticeable impact on particular firms only in the long run and would not be cited in a business survey. Third, all of the arguments in the famous Machlup-Lester debate on whether firms maximize profits are relevant here. ${ }^{24}$

I would argue that good jobs are scarce, relative to a Pareto optimum, but that this inefficiency results from factors long recognized in the neoclassical model and not from the dualist type of inefficiencies. Market power-whether in unions or in oligopolies-results in a socially inefficient undersupply of good jobs. High wages that are not offset by saving in turnover costs reduce the output of the primary sector (and hence the derived demand for good jobs) and generate a substitution toward capital and away from skilled labor. Also, as Becker has explained, imperfections inherent in the labor market result in underinvestment in specific training. Since workers cannot sign voluntary indenture contracts, investment in specific training is necessarily more risky than investment in physical capital. The result is a discrepancy between private and social returns to specific training.

\section{The Secondary Labor Market}

The dual literature on employment in the secondary market has concentrated on four hypotheses: First, there actually is a secondary market that pays lower wages than a primary market. Second, its wage determination

24. For the genesis of the debate, see Richard A. Lester, "Shortcomings of Marginal Analysis for Wage-Employment Problems," American Economic Review, Vol. 36 (March 1946), pp. 63-82; and Fritz Machlup, "Marginal Analysis and Empirical Research," American Economic Review, Vol. 36 (September 1946), pp. 519-54. The controversy elicited comments from other authors and the debate continued for several years in the same journal. Thurow and Lucas, "Distribution of Income," is also relevant here. Actually this study is open to two interpretations: first, that formal education has no market value so that it produces no abundance of skilled workers; second, and related to the Piore argument, that although education does create good workers, firms are unresponsive to relative factor availabilities. In either case, the job structure is fixed. The Thurow and Lucas evidence is indirect, however, and shows only that the narrowing of the distribution of education among workers since World War II has not been accompanied by a narrowing of the distribution of income. Other interpretations could explain this result without resorting to the arguments that education has no value or that the job structure is fixed. 
process differs from that in the primary market, especially by ignoring the major differences in human capital among workers. Third, as a consequence of institutional barriers on the demand side, there is little mobility between the two sectors. Fourth, underemployment is a pervasive characteristic of the secondary market. These issues are discussed in sequence below.

\section{THE STRUCTURE OF THE SECONDARY MARKET}

The secondary market consists of firms with relatively undeveloped internal markets and workers with low wages. The firm has many entry points and few jobs are filled by promotions from within. Firms in this sector generally pay low wages and are largely in the service and wholesale and retail trade sectors. Low-wage firms can be found in any broad sector, however, including manufacturing.

The secondary sector is distinctive because, in part, it employs more than its share of minority workers, teenagers, and children. ${ }^{25}$ Firms in this sector also provide little specific or on-the-job training and relatively limited possibilities for career advancement. These limitations reduce the worker's incentive to remain on the job or to perform exceptionally well. His current wage, unlikely to be significantly improved by promotions, is not greatly different from the opportunity wage in other firms. Similarly, the secondary employer is less reluctant to lay off a worker since he has made no real investment in his training. Hence, "workers in the secondary sector, relative to those in the primary sector, exhibit greater turnover, higher rates of lateness and absenteeism, more insubordination, and ... more ... petty theft and pilferage." More specifically, "high levels of turnover and frictional unemployment may be taken as the salient characteristic of the secondary market." 26

\section{WAGE DETERMINATION}

Wage determination has a micro aspect in fixing the wages paid to individuals and a macro aspect in setting the wage rate in the sector or in-

25. In the Becker terminology, these are the employers with low discrimination coefficients. In the Bergmann model, these are the "crowded" sectors. See Barbara R. Bergmann, "The Effect on White Incomes of Discrimination in Employment," Journal of Political Economy, Vol. 79 (March/April 1971), pp. 294-313.

26. Doeringer and Piore, Internal Labor Markets, pp. 165-66. 
dustry over time. The dualist model has more to say about the former than it does about the latter.

With respect to individual wages, the dualists' primary hypothesis is that a bipolarization of the labor market exists and is analytically or empirically a useful concept. Segmentation may exist within each category of jobs, especially in the primary sector, but not between the two sectors. Unfortunately, the dual literature does not provide an operational definition of good and bad jobs so that an agreed-upon empirical dichotomization does not exist. A data problem with classifying firms is that firms and industries that are principally in the high-wage sector may also be employers in the secondary markets. This apart, the distribution of industries by earnings in the United States plainly shows no dichotomy and, in fact, is reasonably close to a normal distribution. The distribution of workers by earnings also shows no evidence of bipolarity. ${ }^{27} \mathrm{~A}$ simple analysis of wage distributions, however, is not a fair test of bipolarization. More relevant are the attempts to dichotomize the job structure according to wages, but also a host of variables reflecting a job or individual characteristics. Even these results are mixed. In addition, the null hypothesis in all cases is that there is a continuum of jobs. This may be a test of a strict, linear, competitive human capital model, but it is not a satisfactory test of the neoclassical model that recognizes demographic and industrial segmentation. ${ }^{28}$

Whether the dualists believe in a strict dichotomy is unclear. On the surface it makes an expositional and rallying point, effective and dramatic. On the other hand, researchers, including some dualists, obviously take it seriously enough to test for its presence. Whatever their attachment to

27. Data from the special Survey of Economic Opportunity studies in 1966 and 1967 by the Bureau of the Census form uniformly single-peak distributions for whites and nonwhites by urban location. Furthermore, combining the separate categories-suburban ring, central-city poverty area, and rest of central city-also results in single-peaked distributions. See Bennett Harrison, Education, Training and the Urban Ghetto (Johns Hopkins University Press, 1972).

28. See, for example, Arthur J. Alexander, "Income, Experience, and the Structure of Internal Labor Markets," Quarterly Journal of Economics, Vol. 88 (February 1974), pp. 63-85; Paul James Andrisani, An Empirical Analysis of the Dual Labor Market Theory (Ph.D. dissertation, Ohio State University, 1973); Ruth Fabricant Lowell, "The Dual Labor Market in New York City" (paper presented at Human Resources Administration's Welfare Research Conference, New York City, December 1, 1973; processed); and Paul Osterman, "An Empirical Study ${ }_{\llcorner}^{5 /}$ of Labor Market Segmentation," Industrial and Labor Relations Review, forthcoming. 
the idea, their policy views are influenced by the strict dual model. For example, their suggestion of high-wage public service jobs for secondary workers is relatively easy to justify when the alternative is only "bad" jobs. In a more finely segmented market, however, it would involve jumping secondary workers over a broad stratum of jobs, and would raise serious issues of horizontal and vertical equity.

High-wage and low-wage sectors exist, but dichotomization should be used only as a simplifying device. Hereafter, the dual terminology is maintained, but only for expositional purposes.

If bipolarization indeed exists, are the two sectors governed by distinct processes of wage determination? The dualists argue that human capital is largely irrelevant to individual wages in the secondary sector. Employers in this sector, anticipating high turnover, hire workers without much prior screening, and provide little subsequent on-the-job training. Hence, within the sector, individual wages are not a function of the personal characteristics of the worker. Moreover, because promotion is rare and high-wage employment impossible to find, secondary workers exhibit a flat profile of earnings across age groups.

Clearly, the wage processes in the two sectors differ markedly in their institutional arrangements. The wages of individual workers in the primary sector are determined by the workings of the highly structured internal labor market, with the mechanism of supply and demand in the external market operative only at a distance.

The dualist argument that the two markets have different wage processes because the primary sector rewards human capital, whereas the secondary sector does not, is more open to question. Perhaps both sectors obey traditional laws, but have different parameters. To put it another way, alternative job evaluation schemes in the primary sector give different weights to various worker characteristics-that is, "skill" is a multidimensional array. This proposition is already accepted to some extent by the inclusion in both the dual and neoclassical models of years of education and age (as a proxy for on-the-job training) as variables reflecting human capital. But other variables in the skill array, such as quality of schooling and manual dexterity, are omitted because they cannot be measured; hence the coefficients on the human capital terms may be biased and any scalar measure of skill is severely limited and incomplete.

Wachtel and Betsey, and Bluestone, among others, have used regression 
equations to test for the existence of alternative wage processes in the dual labor markets. ${ }^{29}$ They find that "demand variables," such as industry and occupation of workers, are the most important explanatory variables even after "supply effects" such as education, job tenure, age, and the like are included. Although they provide interesting empirical information, these studies hardly test the dualist model. Their view of the neoclassical wage model is a straw man in that it consists merely of the relationship between wages and years of education. This type of equation has been employed by some who follow the human capital approach to estimate returns to education, but it is most often utilized when additional variables are not available. Indeed, multivariate supply-and-demand models of wages, of the type estimated by the dualists, have been a staple of neoclassical economists for the past twenty years. In these models demand variables are usually viewed as representing union or oligopoly power. ${ }^{30}$ The results are similar, although the rankings of the supply and demand effects are sometimes reversed.

In general, whether supply or demand effects tend to dominate depends largely on the richness of the set of independent variables (and the specific sample period). A persistent problem with the human capital hypothesis is the inability to measure and include in wage equations the quality of education as well as the quantity. For example, ghetto schools are generally regarded as worse than other schools, but attempts to quantify the difference have met with little success. ${ }^{31}$ While measures of on-the-job training exist, they are simplistic. Age or job tenure can hardly be expected to provide an accurate proxy for job training. Demand variables may serve as a proxy for some of these inadequately specified human capital variables.

Consequently, the stress on demand variables does not distinguish the dual model from more traditional views of the labor market. Furthermore, the significance of such variables for policies addressed to the plight of the

29. Howard M. Wachtel and Charles Betsey, "Employment at Low Wages," Review of Economics and Statistics, Vol. 54 (May 1972), pp. 121-29; and Barry F. Bluestone, "Economic Theory, Economic Reality, and the Fate of the Poor," in Harold L. Sheppard and others (eds.), The Political Economy of Public Service Employment (Heath, 1972).

30. An example is Leonard W. Weiss, "Concentration and Labor Earnings," American Economic Review, Vol. 56 (March 1966), pp. 96-117. This article also has references to earlier studies.

31. On the quality issue in segregated schools, see, for example, the Supreme Court decision of 1954 in Brown v. Board of Education (347 U.S. 483). The importance of the quality of education is discussed by Finis Welch, "Education and Racial Discrimination," in Orley Ashenfelter and Albert Rees (eds.), Discrimination in Labor Markets (Princeton University Press, 1973). 
low-wage worker is unclear. For example, they do not guide policymakers in choosing among removing the restrictions in the primary sector, subsidizing specific training, or imposing new restrictions, such as higher minimum wages, on the secondary sector.

Some of the more recent studies of the dual hypotheses identified primary and secondary jobs according to certain job characteristics and then used regression equations to test the similarity of the wage determination processes in the two sectors. ${ }^{32}$ In general they find that the wage equation for the secondary market is somewhat different from that which describes the primary sector. In particular, human capital, measured by years of education, seems to be less significant for wages in the secondary sector. These results are meaningful as far as they go, but they are marred by the aforementioned problem of representing the human capital array by a single variable such as years of education. For workers at the bottom of the educational achievement distribution, quality of education may be especially significant, in part because the quantity of education may depend on state laws. Another serious problem, however, is that truncating the sample into primary and secondary sectors biases the human capital coefficients toward zero as a result of adverse selection. The secondary sector is composed of those who "did not make it," and contains the great bulk of those with low education as well as those who did not succeed in translating their higher education into higher incomes. Clearly, combining these groups suggests a low rate of return to education. ${ }^{33}$ Finally, the parameter of the proxy variable for experience-the age of the worker-may also be biased downward. Whereas all workers accumulate age at the same rate, the rate of accumulation of experience or training differs systematically among industries.

A seemingly important contention of the dualists is that the very concentration of poverty in certain segments of the population is proof that a nonneoclassical secondary sector exists. For example, Vietorisz and Harrison argue that "when bad jobs are found to be so widespread that perhaps 60 percent of workers in the inner city fail to earn enough to support a family at even minimum levels of decency, conventional explanations

32. See note 28 above.

33. This point was suggested to me by Glen Cain. See, for example, Glen G. Cain and Harold W. Watts, "Toward a Summary and Synthesis of the Evidence," in Cain and Watts (eds.), Income Maintenance and Labor Supply: Econometric Studies (Markham, 1973). 
Table 1. Low-Income Families, by Number of Earners and Work Experience of Head, 1959, 1963, 1969, and 1973

Numbers in thousands

\begin{tabular}{|c|c|c|c|c|c|c|c|c|}
\hline \multirow{2}{*}{$\begin{array}{l}\text { Number of } \\
\text { earners and } \\
\text { work } \\
\text { experience }\end{array}$} & \multicolumn{2}{|c|}{1959} & \multicolumn{2}{|c|}{1963} & \multicolumn{2}{|c|}{1969} & \multicolumn{2}{|c|}{1973} \\
\hline & Number & Percenta & Number & Percenta & Number & Percent ${ }^{\mathrm{a}}$ & Number & Percent ${ }^{\mathrm{a}}$ \\
\hline \multicolumn{9}{|l|}{ Earners in family } \\
\hline None & 1,981 & 24 & 1,991 & 26 & 1,790 & 36 & 1,841 & 38 \\
\hline One & 4,030 & 48 & 3,463 & 46 & 2,144 & 43 & 2,023 & 42 \\
\hline Two or more & 2,309 & 28 & 2,100 & 28 & 1,071 & 21 & 964 & 20 \\
\hline \multicolumn{9}{|l|}{$\begin{array}{l}\text { Work experience } \\
\text { of head }\end{array}$} \\
\hline \multirow{2}{*}{$\begin{array}{l}\text { Worked, total } \\
\text { Worked full time, } \\
50-52 \text { weeks }\end{array}$} & 5,620 & 68 & 4,836 & 64 & 2,711 & 54 & 2,482 & 51 \\
\hline & 2,617 & 31 & 2,215 & 29 & 1,067 & 21. & 879 & 18 \\
\hline
\end{tabular}

Sources: U.S. Bureau of the Census, Current Population Reports, Series P-60, No. 91, "Characteristics of the Low-Income Population: 1972" (1973), Table 4, p. 26, and Series P-60, No. 94, "Characteristics of the Low-Income Population: 1973"' (1974), Table 5, p. 8.

a. Of total low-income families.

based on individual differences in labor productivity become incredible." 34 But neoclassical economics does not claim that poverty will disappear, and even Adam Smith predicted that it would be concentrated in certain groups of the population. In addition, poverty declined steadily-among families with wage earners-over the period in which consistent poverty data from the Current Population Survey has been published (1959-73—see Table 1). The dualists, however, do not seem to subscribe to the official government definition of poverty, apparently preferring not only a higher cutoff point, but also one that rises with the average income of the nonpoor. Under a purely relative definition, poverty decreases only when the income distribution is compressed. In this case, however, the continuing existence of poverty in no way contradicts any interpretation of the neoclassical model.

An important unexplored topic in the dual literature is the industrial wage differential between the high- and low-wage sectors. The lack of attention to the aggregate-sector or industry-specific wage rates, as distinct from the wages received by individuals, is probably related to the microeconomic focus of the dualist literature, as well as to the greater difficulty in classifying industry data than individual data into primary and secondary sectors. But the question is an important one for understanding the me-

34. Thomas Vietorisz and Bennett Harrison, "Labor Market Segmentation: Positive Feedback and Divergent Development," in American Economic Association, Papers and Proceedings of the Eighty-fifth Annual Meeting (American Economic Review, May 1973), p. 366. 
chanics of the secondary labor market as well as the income distribution between the two sectors.

A traditional, neoclassical analysis would view the relatively structureless secondary market as dominated by supply and demand. Most exponents of the dual approach do not seem to accept the notion that traditional forces of supply and demand supplemented by relevant social legislation (on minimum wages for example) determine the wage rate in the secondary sector ${ }^{35}$ Some argue that since the secondary market is dominated by women and blacks, the institutional degree of racism and sexism determines wage rates. In the orthodox model, discrimination causes a crowding of the secondary sector which reduces wages there below what they would be if the overall economy were competitive, but the partial equilibrium forces of supply and demand specific to the secondary market still determine wages.

Alternatively, the wage rate may reflect a perfectly elastic supply curve of workers at some wage determined largely by custom or subsistence. Although the determinants of "custom" are unspecified, social legislation, especially public assistance, seems to be important in the dualists' framework. Their contention that jobs are abundant in the secondary sector suggests that the social minimum is dictated by the reservation wage of workers. The dualists themselves, however, are reluctant to view the level of public assistance (which they regard as too low) as a determinant of the supply of labor.

A third dualist argument, which is based on the previous points, is that, since discrimination and low levels of public assistance are responsive to political legislation, the secondary wage is determined by political and social forces. Granted that a political model to explain government policy endogenously would be of great interest, neither political scientists nor economists of whatever persuasion have been successful in creating one.

Although the dualists have not yet completed a theory of the determination of the secondary wage, some argue that wage differentials between the primary and secondary sectors are tending to widen. ${ }^{36}$ According to the hypothesized mechanism, high profits in the primary sector allow firms to pay

35. This group views the wage as fixed by the needs of society for low-paid workers to do dirty jobs. "The wealthy in this country have become accustomed to the services supplied by cheap labor and have little desire to pay decent wages for such things as laundered shirts and garbage collection" (Bluestone, "The Fate of the Poor," p. 127).

36. Vietorisz and Harrison, "Positive Feedback." 
for considerable on-the-job training, which in turn raises productivity and yields a return on the investment that is shared by workers and employers in the form of higher wages and profits. The higher profits then generate another cycle of human capital investment, higher wages, and so forth. This analysis has a number of problems, including its use of absolute levels rather than margins as a measure of profitability and its assumption that profits will always be plowed back into more human capital in the highwage sector. The last is especially troublesome when firms operate in both the primary and secondary markets.

Moreover, the evidence suggests that such influences are dominated by more traditional supply and demand elements which prevent a divergent wage structure. Although the industrial wage structure has widened somewhat in the postwar period, most of that movement is attributable to cyclical forces and, in particular, the very narrow wage dispersion that resulted from the tight labor market conditions during World War II.

\section{MOBILITY AND BARRIERS TO THE PRIMARY SECTOR}

One of the most crucial hypotheses of the dualist model is that barriers between the primary and secondary sectors that are not based on human capital prevent mobility between the two sectors. As described by Bluestone,

many of those who suffer from low wages and unemployment have a considerable amount of human capital. They fail to find jobs which pay a living wage because of racism, sexism, economic depression, and uneven economic development of industries and regions.... Given the opportunity to escape to the high-wage sector, many low-wage workers would perform admirably. Without years of extra education, without massive doses of institutional and on-the-job training, without learning a new "industrial discipline," many low-wage workers could fit into a unionized, profitable, capital-intensive industry and begin to earn a living wage. ${ }^{37}$

Unfortunately, an impartial test of the mobility model is difficult to formulate. The "small amount" of mobility that would confirm the dual model

37. Bluestone, "The Fate of the Poor," pp. 121, 123. Garth L. Mangum agrees: "The basic manpower obstacle is still the supply of [good] jobs. Even during 1966-68 when labor markets in general were tight, there were never enough jobs in rural depressed areas or central city ghettos within the occupational ranges attainable by the disadvantaged. ..." See his "Manpower Research and Manpower Policy," in Industrial Relations Research Association Series, A Review of Industrial Relations Research, Vol. 2 (University of Wisconsin, IRRA, 1971), pp. 109-10. 
remains to be defined. At what point does the dual model become indistinguishable from a neoclassical segmentation model, such as the one suggested by Holt?

The evidence on the mobility issue clearly refutes a literal interpretation of the dualist model. The recent micro studies that dichotomize the job structure of the economy in the manner outlined by the dual literature suggests a significant amount of mobility between the two sectors. ${ }^{38}$ The macro study by Okun also strongly supports mobility, revealing, in a cyclical, time series context, a substantial amount of upgrading during the economic expansion of the late 1960s. ${ }^{39}$

In drawing a definite boundary between the two sectors, Doeringer, Piore, and others had suggested that aggregate demand policies would lead the primary sector to subcontract work to the secondary sector rather than increase its own employment. Although some subcontracting may have occurred during the recent expansion, Okun's analysis shows that the employment boundaries were also significantly pierced. ${ }^{40}$ Although the ultimate result was to force the monetary and fiscal authorities to brake an inflationary economy, the findings have important implications for the dual literature. Indeed, the inflationary consequences heighten the significance. Contrary to the dualist model, which views primary and secondary workers as close substitutes, the increase in the inflation rate in the late 1960s supports the neoclassical position that secondary workers can be integrated into primary jobs only with some difficulty in the form of more, or costlier, training. It points to the presence of bottlenecks in the supply of different skills rather than widespread underemployment within a relatively homogeneous labor force, as charged by the dualists.

\section{UNDEREMPLOYMENT: LOCKING GOOD WORKERS INTO}

THE SECONDARY SECTOR

The dualists agree that some secondary jobs are filled with lower-skilled workers-teenagers beginning their work careers with little education, females interested in part-time employment, and workers with low aptitude

38. See the first three articles listed in note 28 above for examples. Results of work in progress, reported by Robert E. Hall in a personal conversation, suggest quite extensive mobility.

39. Okun, "Upward Mobility."

40. See, for example, ibid., p. 208. 
and hence low human capital and skill. The central claim of the dual approach, however, is that this successful matching of unskilled workers and secondary jobs is overemphasized in the neoclassical model. Rather, the dualists support the contrary hypothesis: that underemployment is pervasive, in that good workers are locked into bad jobs.

Once a strict dual model yields to a more generally segmented model, the question of whether good workers are locked into bad jobs becomes more complex. Exclusion of secondary workers from the "good" jobs in the primary sector is relatively easy to visualize theoretically, given the barriers to entry erected by oligopolies and unions. But exclusion from the "fair" jobs in the "gray" sectors, where entry is relatively easy, is harder to understand. If the good workers are there, why don't new firms enter the market and utilize their talents? Four explanations have been offered for this lack of competitive response: discrimination, feedback, life-cycle effects, and information externalities.

Discrimination. According to the dual literature, discrimination-particularly racial discrimination-is the major institutional barrier that confines certain workers to the secondary sector. This is illustrated by the lower returns to education for inner-city, low-wage blacks than for inner-city, low-wage whites that Harrison found. ${ }^{41}$ Mobility studies also indicate that blacks have a more difficult time in escaping from the secondary sector once they take their first job there. Finally, the proportion of blacks employed in the secondary sector far exceeds that in the labor force.

Clearly, discrimination plays a central role in the dualist view of the working of the labor market and the importance of underemployment. Barriers to upward mobility can be posited on pervasive social mores without resort to radical arguments of employer collusion. Unfortunately, there is neither a generally acceptable neoclassical nor dualist theory of discrimination.

Although the dualists have analyzed the empirical importance of discrimination, they have not investigated the extent to which ongoing discrimination exerts its force in the labor market rather than before workers enter it. This issue, however, is crucial to their policy views. By largely ignoring pre-labor market discrimination, the dualists can downplay manpower training and stress underemployment. It is difficult, however, to judge whether blacks are seriously disadvantaged in labor markets currently, given the endowments they bring to market. Their endowments may

\section{Harrison, Education, Training, and the Urban Ghetto.}


be inaccurately measured because of the inability to measure the quality of schooling and to capture feedback from such variables as the socioeconomic status of the parents. For example, Hall and Kasten, who included a socioeconomic status variable as part of the labor market endowment of blacks, concluded that "while the sixties saw the nearly complete elimination of racial bias in the way that the labor market assigned individuals to occupations, literally no progress was made during the period in augmenting the endowments of blacks relative to whites." 42 Furthermore, Freeman finds that government policies, especially on the state and local levels, are largely responsible for the poor labor market endowments of blacks. ${ }^{43}$

Feedback restraints. Do low-wage workers need additional training to compete with primary-sector workers? The dualists are involved in an ambiguity in addressing this key question. On the one hand, the dual literature (especially Piore ${ }^{44}$ ) has made an important contribution by concentrating on feedback mechanisms in secondary employment, which, through unstable employment relationships, encourage workers who hold "bad" jobs to become "bad" workers-or, more precisely, to adopt bad work habits. The dualists, however, have ignored some of the implications of the feedback model in explaining barriers. Once the worker in the secondary sector has developed bad habits (or received feedback), he is less skilled and less trainable than the primary-sector worker and thus, unlike the victim of discrimination, he is not underemployed.

In addition, the proposition that workers are influenced by the instability of their jobs to become more unstable in their work attachments is only part of a larger system of feedback, in which workers are influenced by

42. Robert E. Hall and Richard A. Kasten, "The Relative Occupational Success of Blacks and Whites," BPEA (3:1973), pp. 791-92.

43. Richard B. Freeman, "Alternative Theories of Labor-Market Discrimination: Individual and Collective Behavior," in von Furstenberg and others (eds.), Patterns of Racial Discrimination, Vol. 2. Court rulings, following the 1971 Griggs v. Duke Power Co. decision (401 U.S. 424), have, in effect, adopted the dualist view of the workings of the labor market. The decision makes almost no effort to control for the lower labor market endowments of blacks. For example, with blue-collar occupations, the courts commonly find labor market discrimination when the percentage of blacks in the firm is substantially lower than the percentage of blacks in the community. This may be good social policy-or at least it is aimed at achieving a desirable social end-but its economic underpinning is open to controversy.

44. Michael J. Piore, "Jobs and Training," in Samuel H. Beer and Richard E. Barringer (eds.), The State and the Poor (Winthrop, 1970). Feedback effects have received more attention from radical economists than from the dualists. 
many socioeconomic factors including their family background. Some sociologists and psychologists who have focused on feedback effects have been led to formulate the "culture of poverty" hypothesis. ${ }^{45}$

Feedback models have received increasing attention in the economic literature. For example, according to Arrow's work on discrimination, blacks who believe that they will receive a lower rate of return from their training will undertake less training-specific as well as general. They then ensure a self-fulfilling prophecy: if employers originally discriminate because they believe that blacks are not good workers, then blacks will turn out to be less skilled workers because they will invest less in education. ${ }^{46}$

Empirically, feedback effects appear to be important, whether measured by variables reflecting attitudes or socioeconomic status. ${ }^{47}$ According to Goodwin, welfare mothers communicate to their children a sense of inadequacy that may inhibit labor force behavior. Since 15 percent of the children in this country (10 percent of white children and 38 percent of nonwhite ones) are reared in low-income families, and over 20 percent of the current group of young workers spent their childhoods in poverty, a sizable proportion of today's and tomorrow's work force is vulnerable to attitudes that compromise their full economic development. Furthermore, some poor children bear an additional handicap in that they are raised in relatively large families-a disproportionate number of families with four or more children are in the poverty category (see Table 2). Evidence indicates that children growing up in large families tend to achieve less education and are otherwise less well endowed than those from smaller families.

In a study using identical twins, in which shared environmental experiences in childhood and genetic effects could be studied, Taubman estimated that these two effects explained almost one-half of the total variation in wages among individuals. ${ }^{48}$ Although economic research into feedback is only beginning, it appears to be an important and promising area.

45. For the culture-of-poverty hypothesis see, for example, Daniel P. Moynihan (ed.), On Understanding Poverty: Perspective from the Social Sciences (Basic Books, 1969); and Edward C. Banfield, The Unheavenly City (Little, Brown, 1968).

46. Kenneth J. Arrow, "The Theory of Discrimination," in Ashenfelter and Rees (eds.), Discrimination in Labor Markets.

47. See, for example, Andrisani, "Dual Labor Market Theory"; and Leonard Goodwin, Do the Poor Want to Work? A Social-Psychological Study of Work Orientations (Brookings Institution, 1972).

48. Paul Taubman, "The Determinants of Earnings: A Study of White Male Twins" (University of Pennsylvania, 1974; processed). In general, the environmental experience of a family cannot be differentiated from genetic effects. 
Table 2. Distribution of Children in Low-Income and Nonpoor

Families, By Size of Family, 1972

Thousands, except as noted

\begin{tabular}{|c|c|c|c|c|}
\hline \multirow[b]{2}{*}{$\begin{array}{l}\text { Size of family and } \\
\text { mean statistic }\end{array}$} & \multicolumn{2}{|c|}{ Low-income families ${ }^{\mathrm{a}}$} & \multicolumn{2}{|c|}{ Nonpoor families } \\
\hline & $\begin{array}{l}\text { Per- } \\
\text { centage }\end{array}$ & $\begin{array}{l}\text { Total number } \\
\text { of children }\end{array}$ & $\begin{array}{l}\text { Per- } \\
\text { centage }\end{array}$ & $\begin{array}{l}\text { Total number } \\
\text { of children }\end{array}$ \\
\hline \multicolumn{5}{|l|}{$\begin{array}{l}\text { Number of related } \\
\text { children under } 18\end{array}$} \\
\hline None & 28.7 & 0 & 44.9 & 0 \\
\hline One & 18.9 & 958 & 20.2 & 9,947 \\
\hline Two & 17.0 & 1,720 & 18.1 & 17,848 \\
\hline Three & 13.3 & 2,034 & 9.8 & 14,433 \\
\hline Four & 9.9 & 2,012 & 4.2 & 8,272 \\
\hline Five & 6.9 & 1,745 & 1.7 & 4,070 \\
\hline Six or more & 5.3 & 1,626 & 1.2 & 3,678 \\
\hline Total & 100.0 & $10,095^{b}$ & 100.0 & $58,248^{b}$ \\
\hline \multicolumn{5}{|l|}{ Mean number of children } \\
\hline Per family & $\ldots$ & 1.99 & $\ldots$ & 1.18 \\
\hline Per family with at least & & & & \\
\hline one child & $\ldots$ & 2.79 & $\ldots$ & 2.14 \\
\hline In family per child & $\ldots$ & 3.67 & $\ldots$ & 2.82 \\
\hline
\end{tabular}

Sources: Bureau of the Census, Series P-60, No. 91, "Characteristics of the Low-Income Population, 1972," Table 38, pp. 117-19; and Series P-60, No. 90, "Money Income in 1972 of Families and Persons in the United States" (1973), Table 21, p. 59. The percentage details may not sum to 100 due to rounding.

a. The definition of low income varies with family size.

b. Differs from that in source because of statistical discrepancy.

Feedback models do not support the conclusion that better jobs, rather than better training, are the answer to the low-wage problem. They do suggest, however, that manpower training of adult workers is likely to be a costly process, which must remedy not only deficiencies in past education, but also the negative signals that the worker has received from society. This confirms the conventional wisdom that attempts to narrow the distribution of human capital should focus on the early years of education. Although the dualists have ignored some of the implications of their work on feedback effects, most neoclassical economists have ignored them altogether. Tastes are unimportant to those who see behavior as supply responses to different market opportunities facing individuals and families.

Life-cycle effects. Both neoclassical and dual economists have explored the way unanticipated declines in labor demand have trapped individuals in disadvantageous geographical areas, occupations, or specialized industries. One manifestation is that skilled individuals may be found in bad jobs. 
The dualists appear to regard this as a failure in the equalizing mechanism of the neoclassical model. This is not the case. The equalizing tendencies of the neoclassical model work in the labor market, but they work across cohort groups. With finite life spans, individuals cannot repeatedly take new decisions on human investment or career. Each cohort attempts to avoid the mistakes and overcome the handicaps of its predecessors, but it may not have the time to correct its own errors or to avoid the new barriers that a dynamic economy may create.

Information externalities. If workers or firms have imperfect information about the qualifications of workers (or the skill requirements of firms), multiple equilibria may exist and the economy may settle at a suboptimal point. In particular, imperfect information may upset the normal ordering of workers and jobs so that good workers become locked into bad jobs. In fact, information is unquestionably imperfect, the economy is in disequilibrium, and many workers do not receive their "perfect information, equilibrium wage." 49 The real issue is an empirical one: how important are these externalities?

To some extent discrimination can be treated as an information externality; for example, employers, uncertain as to the skill of job applicants, hire prime-age white males for the "good" jobs because that demographic group has, on average, the highest average educational achievement and, at least, may be believed to have the best job records. Although many of the dualists deal with discrimination, it seems unlikely that they intend underemployment in the secondary sector to apply only to those groups who provide their own inexpensive signaling mechanism based on demographic characteristics such as race, sex, and age. An unanswered question, however, is whether there is a dual labor market, or significant underemployment in the secondary sector, for prime-age white males. The allocation of jobs among white males raises the general question of the job allocation mechanism within any demographic group (for example, among black females). The neoclassical model predicts that (given that discrimination lowers the earnings of black females) the wage ranking of members within a demographic group depends largely upon such variables as human capital

49. "Recognizing" the true worth of the secondary worker is considerably easier than the "upward-sloping demand curve" notion in the development literature. There, an increase in wages, by increasing nutritional levels, improves productivity. The lagged response of productivity to the increase in wages could conceivably hide the optimal solution from the employer. 
and unionization. It is unclear that the dualists offer an alternative explanation.

The fact that a good deal of variation in family or individual earnings cannot be explained in regression analysis is not supporting evidence for the dualist model. Although some interpret the residual in earnings equations as proving the importance of "luck," or nonneoclassical variables, in determining the income distribution, ${ }^{50}$ the residual may as readily be the missing "perfect" measure of IQ or the quality of education. The real problem is to formulate measurable independent variables that can explain underemployment and differentiate between the competing theories.

To summarize, both the neoclassical and dual models can encompass underemployment, in which good workers are locked into bad jobs. The neoclassicists lay the blame for it on discrimination and life-cycle effects, while the dualists see it as pervasive among secondary workers, presumably including prime-age white males. A rigorous empirical test of the dual underemployment hypothesis, however, has not been attempted, and given the available data, may not be feasible.

\section{The Poverty-Unemployment Nexus}

\section{THE NEW STRUCTURAL UNEMPLOYMENT}

One major thrust of the dual literature is its new interpretation of unemployment in the secondary sector. Even when aggregate unemployment rates fall below 4 percent, unemployment in secondary labor markets remains quite high. The dualists argue that in spite of these high unemployment rates, anyone who wants a typical secondary job can work because vacancies are abundant at the prevailing wage rate for such jobs. The problem is that as a consequence of low wages, poor promotion possibilities, and "bad" jobs, individuals choose not to work steadily on any one job. Facing only low costs of specific training and turnover, employers, for their part, have no incentive to encourage stability and, in certain circumstances, may actually discourage it-for example, when unionization is a threat. The implicit hypothesis that the worker's wage is below his reservation wage suggests, as discussed below, that the unemployment is structural. Thus, high quit rates, high unemployment rates, and high

50. See, for example, Christopher Jencks, Inequality: A Reassessment of the Effect of Family and Schooling in America (Basic Books, 1972). 
vacancy rates coexist as workers move among jobs and in and out of unemployment and the labor force. For many secondary workers, the combination of low wages with periods of unemployment or nonattachment to the labor force means family incomes below the poverty level.

According to the dualists the character of this unemployment cannot be explained readily in the neoclassical framework. However, the dual model of unemployment is compatible with neoclassical theory; that is, the dualists have suggested different parameters for a more orthodox model of structural unemployment. ${ }^{51}$ For example, the explanation for structural unemployment offered by the Keynesians in the early 1960s was that certain groups of workers were isolated in geographical regions, or in occupations characterized by inadequate demand, and thus encountered difficulties in finding employment. These workers would, for a time, be a component of the long-term unemployed and finally would drop out of the labor force, thus joining the "hidden unemployed" composed of discouraged workers. ${ }^{52}$ This older view emphasizes the excess supply of low-skilled workers, whereas the dual model stresses the adequacy of demand for secondary workers. The concern of the dualists has thus switched from problems of inadequate demand for workers to the low wages available to secondary workers.

The theoretical underpinnings of the dualist position may be reconstructed in neoclassical form. Workers may be viewed as maximizing utility. Family income depends upon the wages offered, upon hours worked by family members, and upon transfer payments that set a floor on the standard of living, and also vary with wage income (as is the case with food stamps). The higher the benefit level relative to the wage rate, the more likely that the working members of the family will choose not to work full-time the year round. This unemployment, however, does not fit a traditional job-search model, in which periods of unemployment are spent searching for a better job. Instead, individuals in the secondary market seem to move from one bad job to another. The findings are consistent with the timing phenomenon suggested by Mincer. ${ }^{53}$ If benefits are more

51. Indeed, some neoclassical economists were coincidentally reporting the same findings as those reported by the dualists. See Hall, "Why Is the Unemployment Rate So High?"

52. The notion that a significant discouraged-worker effect is concentrated in the early 1960s is stated in Michael L. Wachter, "A Labor Supply Model for Secondary Workers," Review of Economics and Statistics, Vol. 54 (May 1972), pp. 141-51.

53. Jacob Mincer, "Labor Force Participation of Married Women: A Study of Labor Supply," in Aspects of Labor Economics, A Conference of the Universities-National 
easily received and if labor is less onerous when the individual works only part of the year, the pattern of instability observed by the dualists emerges. Rather than work at random, however, individuals will attempt to participate when jobs are easiest to find and wages are relatively high. Furthermore, although upward mobility from the low- to the high-wage sector may be limited, searching for a higher-paying and better secondary job may be worthwhile-especially when the income lost by not working is relatively small. In a multisector (rather than dual) market, the potential gains from search increase.

The unemployment model can be generalized in a straightforward manner to include both the pure timing aspect and the queuing for jobs in the high-wage sector (or alternatively, the better jobs in the low-wage sector). ${ }^{54}$ The utility-maximization problem is broadened so that the worker decides on hours of labor force attachment, given the wage in the low-wage sector and the wage and perceived probability of finding employment in relatively high-wage sectors. The model thus determines, for secondary workers, (1) the supply of labor to the low-wage sector; (2) the length of the queue in the relatively high-wage sector; and (3) the amount of time spent out of the labor force.

\section{EVIDENCE ON SHIFTS IN STRUCTURAL UNEMPLOYMENT}

In view of the disagreements about the empirical nature of unemployment, an important issue is whether structural unemployment has been changing over time. Are the job instability and excess supply that the dualists cite relatively new or have they prevailed for a generation? The dualists focus their empirical work on the late 1960s and early 1970s. The dualist view of unemployment implies a strongly pessimistic assessment of aggregate demand management which in turn leads to their policy recommendation for the government to create more good jobs. That recommendation is particularly questionable since it is supported only by cross-section

Bureau Committee for Economic Research (Princeton University Press for the National Bureau of Economic Research, 1962). Although Mincer's model is designed to explain the behavior of females who had only partial commitment to the labor force, the timing effect is applicable to all secondary workers.

54. A model of queuing unemployment is presented in Stephen A. Ross and Michael L. Wachter, "Wage Determination, Inflation, and the Industrial Structure," American Economic Review, Vol. 63 (September 1973), pp. 675-92. 
studies. Moreover, that limitation is inherent, given the lack of time series evidence on the dynamics of the unemployment problem.

The evidence for the 1948-73 period-especially for the past decadesuggests that the incidence of unemployment has shifted to the disadvantage of demographic groups most likely to be represented in the secondary sector, particularly males aged 16-24 and females 16-44 relative to primeage males. ${ }^{55}$ While the incidence among young secondary workers of both sexes has increased, the duration of their unemployment spells has declined, according to the evidence presented by Perry. In other words, unemployment for secondary workers has been increasingly marked by shorter but far more frequent spells. ${ }^{56}$ These trends are especially striking in view of the relative increase in employment in nonmanufacturing, the major source of jobs for secondary workers, and the narrowing of wage differentials between black and white workers. Both of these factors implied an improvement rather than a decline in the employment stability for secondary workers.

Welfare judgments about this growing incidence of unemployment among secondary workers are hazardous, however. There has, for example, been a steady decline in the poverty population, especially among families with at least one wage earner. Meanwhile, the bottom fifth of the income distribution has had a roughly constant share of income. Furthermore, during the 1960s young black workers achieved sharper income gains than did whites and older blacks. ${ }^{57}$

55. This is based on results obtained by regressing the unemployment rate of each demographic group on the unemployment rate for prime-age males and a time trend. Both a continuous time trend and a time trend broken in 1962 were tested. See also R. A. Gordon, "Some Macroeconomic Aspects of Manpower Policy," in Lloyd Ulman (ed.), Manpower Programs in the Policy Mix (Johns Hopkins University Press, 1973); and George L. Perry, "Changing Labor Markets and Inflation," BPEA (3:1970), pp. 411-41.

56. George L. Perry, "Unemployment Flows in the U.S. Labor Market," BPEA (2:1972), pp. 245-78. Although the incidence of unemployment for older black males has improved slightly, their labor force participation rates have fallen dramatically. Hence, the changing pattern of labor market behavior may have affected older blacks in the secondary sector by decreasing their participation rates rather than increasing their unemployment rates.

57. Richard B. Freeman, "Changes in the Labor Market for Black Americans, 194872," BPEA (1:1973), pp. 67-120. The discrepancy between the income and unemployment experiences of young blacks may reflect a growing variance in black economic performance. 
The changing nature of unemployment, with the associated poverty problems, raises important questions. First, why has the incidence and duration of unemployment changed? Second, is the economy now fixed into the new pattern or are further alterations likely?

Although these questions raise issues that go far beyond the scope of this paper, answers to them are needed to evaluate the policy proposals recommended in the dual literature. Several broad developments in the secondary market may have accounted for the increasing instability. First, the relative cost of being unemployed or out of the labor force has declined as a result of government transfer programs. Although that relative cost should affect unemployment, according to the underlying reasoning of the dualists, it is not included explicitly in their argument. Their field work and empirical analysis indicate that workers in the secondary market move frequently between work in the low-wage sector and the welfare sector (and also between those two sectors and the "irregular economy" of illegal and quasi-legal work). ${ }^{58}$ The higher the level of welfare payments, the less time workers are forced to spend in secondary jobs.

The relative protection against unemployment and poverty increased substantially in the late 1960s and early 1970s. The average benefit payment to a recipient of aid to families with dependent children (AFDC) has increased by 103 percent from 1963 to 1974, while average hourly earnings have increased by only 85 percent, ${ }^{59}$ and has also increased relative to the minimum wage. Moreover, the effective coverage of AFDC has vastly expanded, as have in-kind transfers to the poor, especially food stamps, child

58. Vietorisz and Harrison, "Positive Feedback," for example, states that "the welfare system is an integral part of this vicious circle. On the one hand, it acts as a payroll subsidy to secondary employers; on the other hand, it maintains living levels low enough to force a steady flow of labor supply into the secondary labor market" (p. 366). Although they would prefer welfare payments to be high enough so that the low-wage earners could avoid working, they clearly recognize that the labor supply of secondary workers is responsive to the level of benefits. See also, Harrison, Education, Training, and the Urban Ghetto, especially Chap. 5. An impressive and detailed study of the large disincentive effects of the welfare system is contained in various reports in Studies in Public Welfare, Prepared for the Use of the Subcommittee on Fiscal Policy of the Joint Economic Committee, 92 Cong. 2 sess (1972), and 93 Cong. 1 sess., 2 sess. (1973, 1974).

59. Employment and Earnings, Vol. 21 (July 1974), Table C-1, p. 91; U.S. Department of Health, Education, and Welfare, Trend Report: Graphic Presentation of Public Assistance and Related Data ... 1971 (1972), p. 7; and unpublished data from the U.S. Bureau of Labor Statistics and HEW. 
nutrition, housing subsidies, and medicaid. From 1967 to 1972, in-kind benefits increased 700 percent, while cash payments (consisting of social security, public assistance, veterans' compensation, and unemployment benefits) rose 72 percent. In 1972 average AFDC payments for a recipient family of four with no income were $\$ 2,947$. In the unusual case in which the family also received food stamps, public housing, and medicaid, benefit levels would have been $\$ 5,349$ (equivalent to $\$ 6,015$ of taxable income), 25 percent above the poverty threshold for 1972 and even exceeding the pay for many full-time secondary jobs. ${ }^{60}$

A second possible explanation for the growth of employment instability is associated with the growing share of the 16-24 age groups in the labor force ${ }^{61}$ The sharp increase in the percentage representation of young women in the labor force that occurred between 1960 and 1973 reflected both the growing percentage of the young in the population (a consequence of the baby boom of the late 1940s and 1950s-see Table 3) and rising participation rates. The change in the percentage of young males in the labor force was smaller, reflecting a nearly constant participation rate, but also positive. This overall increase in the representation of young workers in the labor force is of great importance, not only because of their especially high turnover and unemployment rates but also because, to the extent that they are imperfect substitutes for older workers, an increase in their relative number may have caused the increase in their already high unemployment rates. ${ }^{62}$ Since young workers have not had the time to acquire specific training, they are most competitive with secondary older workers. Hence, ceteris paribus, the influx of young workers may well have depressed wages

60. The poverty level was $\$ 4,275$ in 1972 ; see Bureau of the Census, Series P-60, No. 91, p. 141 (cited in Table 1 above), and James R. Storey, "Welfare in the 70's: A National Study of Benefits Available in 100 Local Areas," Studies in Public Welfare, Paper 15, p. 4. In 1972, almost all AFDC recipients were eligible for medicaid, 69 percent received food stamps or commodities, and 14 percent were living in public housing units (Storey, p. 3). It should be recognized that the income data that measure the poverty population (as in Table 1) do not include in-kind transfers.

61. There is some evidence that the increasing coverage of minimum wage laws may also have contributed to the instability problem in the secondary sector. See, for example, Marvin Kosters and Finis Welch, "The Effects of Minimum Wages on the Distribution of Changes in Aggregate Employment," American Economic Review, Vol. 62 (June 1972), pp. 323-32.

62. The imperfect substitution argument is an important component of Richard A. Easterlin, Population, Labor Force, and Long Swings in Economic Growth: The American Experience (Columbia University Press for the National Bureau of Economic Research, 1968). 
Table 3. Distribution of Civilian Labor Force and Population, by Sex and Age Groups, Selected Years, 1950-90

\begin{tabular}{|c|c|c|c|c|c|c|}
\hline \multirow{2}{*}{$\begin{array}{l}\text { Sex and } \\
\text { age group }\end{array}$} & \multicolumn{4}{|c|}{ Actual } & \multicolumn{2}{|c|}{ Projected $^{\mathrm{a}}$} \\
\hline & 1950 & 1960 & 1970 & 1973 & 1980 & 1990 \\
\hline \multicolumn{7}{|c|}{ Percent of civilian labor force, aged 16 and over } \\
\hline Males & & & & & & \\
\hline 16 to 24 & 11.5 & 9.9 & 11.7 & 13.2 & 12.4 & 9.2 \\
\hline 25 to 54 & 45.7 & 44.2 & 38.9 & 37.8 & 38.6 & 42.8 \\
\hline 55 and over & 13.3 & 12.5 & 11.2 & 10.0 & 9.8 & 8.5 \\
\hline \multicolumn{7}{|l|}{ Females } \\
\hline 16 to 24 & 7.1 & 6.7 & 9.8 & 10.6 & 10.3 & 8.1 \\
\hline 25 to 54 & 18.6 & 21.1 & 22.0 & 22.4 & 22.7 & 25.5 \\
\hline 55 and over & 3.9 & 5.6 & 6.3 & 5.9 & 6.3 & 5.8 \\
\hline
\end{tabular}

Males

16 to 24

Percent of total population, aged 16 and over ${ }^{\mathrm{b}}$

25 to 54

55 and over

Females

16 to 24

25 to 54

55 and over

$\begin{array}{rr}9.3 & 9.0 \\ 28.6 & 27.4 \\ 11.5 & 12.4\end{array}$

9.0

11.5

11.6

11.4

8.8

12.4

24.5

24.5

25.0

28.0

12.1

11.9

11.6

11.2

\footnotetext{
Sources: Manpower Report of the President, 1974, Tables A-3, E-2, E-7, pp. 255, 350, 353; Bureau of the Census, Current Population Reports, Series P-25, No. 519, "Estimates of the Population of the United States, by Age, Sex, and Race: April 1, 1960 to July 1, 1973" (1974), Table 1, pp. 12, 15, 25; and Series P.25, No. 311, "Estimates of the Population of the United States, by Single Years of Age, Color, and Sex, 1900 to 1959 " (1965), pp. 22-23.

a. The projected figures are based on official government calculations.

b. Details may not sum to 100 percent due to rounding.
}

in the secondary sector and postponed the improvement of labor force conditions for black males (who are disproportionately represented in the secondary sector).

To the extent that increasing instability has resulted from these demographic shifts, matters should improve with the anticipated reversal of the demographic pattern by the 1980s (reflecting the drop in births in the 1960s and early 1970s). The surfeit of young workers will disappear and primeage workers will become more abundant. Although the next generation of prime-age workers may experience more unemployment than the current generation as a consequence of their unfavorable work experience in their early years, severe job instability should decrease on the whole. The policy implications of these trends are discussed in the final section. 


\section{Policy Issues}

The major policy proposal of the dualists calls on government to create more good jobs, in either the private or the public sphere, but more likely in the latter. Although the dualists do not oppose manpower training, aggregate demand policies aimed at full employment, or transfer payments to the lower-income groups, they argue that these programs have been largely ineffective. Hence the need for direct action. ${ }^{63}$

\section{DIRECT CREATION OF GOOD JOBS}

The private sector. Given the assumption that secondary workers have the human capital that they need to succeed in primary jobs, the creation of additional good jobs is a simple task. The dualists suggest that the government impose on the secondary sector the characteristics of the primary sector, by such methods as increasing the coverage and extent of the minimum wage laws, encouraging unionization, and expanding social legislation in general..$^{64}$ In essence, these dualist proposals are designed to legislate higher wages; and if higher wages are all that is required to convert a poor job into a good one, these policies should work.

63. In concentrating on the issue of creating more good jobs, the dualists have ignored the implications of the feedback effects that are inherent in their own argument. In some sense, they have neglected the cycle of poverty and have assumed more equality among workers than they have evidence to justify. In a broader context, their recommendations can be reinterpreted as means for breaking the cycle at the point of labor market activity. Whether this is a least-cost or even a viable solution is unclear. The social and psychological features of the literature on the cycle of poverty do not encourage optimism on this score.

64. Doeringer and Piore, Internal Labor Markets, pp. 204-08; also Thomas Vietorisz, “We Need a \$3.50 Minimum Wage," Challenge, Vol. 16 (May/June 1973), pp. 49 ff. Adding the cost-of-living increases since the Vietorisz article was published results in a minimum of approximately $\$ 4.15$. This, in turn, translates into a minimum yearly income for the fully employed of $\$ 8,300$.

The unionization policy may not contribute much to this policy package because many industries that are now nonunion could support only weak unions that could achieve little or no wage premium. If product markets are national or international in scope and are easy to enter, then it is difficult to maintain a strongly unionized industry. Where competition is confined to the United States, rules requiring unionization and industry-wide bargaining might succeed. Where international competition is present, even these stringent methods might not drive up wages. 
The main issue about the dualist suggestion is the validity of its basic premise that the needed human capital is present although latent. If this premise is false, legislated wage increases will add to unemployment. The jobless can always be helped by increasing unemployment compensation and public assistance; but these techniques are hardly in the spirit of the dualists' aims. To eliminate the secondary sector, the economy would simply build a larger welfare sector.

The dualists appear to recognize these problems, and some offer policies to offset the problems created by their solution of legislating higher wages. Vietorisz suggests cushioning the disemployment effect by a transitional employment freeze, wage and price controls (but especially the latter), assistance to businesses in industries in which firms are squeezed out by higher wages and the employment freeze, and transitional import controls. ${ }^{65}$ The transition period is expected to be short because the now better-paid secondary workers should quickly respond by increasing their productivity. In the view of neoclassical economists, however, these supplementary policy suggestions, such as employment freezes and import controls, would create much more serious domestic and international problems than even the original undiluted prescription of higher wages.

To the extent that good jobs are defined not only by high wages but also by on-the-job training and promotion possibilities, none of these recommendations is sure to work. Instead, well-developed internal labor markets are needed. Hence, the missing ingredients are measures to encourage capital formation, physical and human, and to discourage turnover in the lowwage industries. These policies would aid in the development of on-the-job training and promotion ladders.

Public service employment. Perhaps because they realize the problems inherent in government-induced creation of good jobs in the private sector, the dualists stress their creation in the public sector, not just to counter cyclical downturns but as permanent placements. The goal is to hire and maintain the structurally unemployed and the working poor in a stable work relationship. Beyond its income-equalization effects the appeal of this policy rests on the notion that those locked into the secondary sector are potentially as productive as primary workers but have been excluded by institutional barriers or a simple scarcity of good jobs. Also, since the dualists believe that there is a large unmet demand for public services (even

65. Ibid, pp. 60-61. 
at the high wage rate that they recommend), the welfare of society as well as the individuals will be enhanced. Secondary workers who lack labor market endowments will profit from the specific training they receive in the government, which will furthermore prepare them to work in the private primary sector.

This proposal runs into the same basic objection as others do: there is no evidence to support the contention that secondary workers have the endowments to qualify for primary jobs. In addition, if this proposal were implemented, it might never become known whether secondary workers do indeed qualify. As an employer of last resort, the government is unlikely to fire those who did not produce and might not worry about price-induced decreases in the demand for public services. Indeed, if it so desired, the government could absorb the entire adult pool of public assistance beneficiaries and the unemployed into its work force. Since government value added is, by convention, measured by the wage bill, gross national product would rise accordingly. Furthermore, the internal labor markets of the various levels of government, ruled by a combination of civil service procedures and political patronage, probably conform more to the dualist view than do those in the private sector. Essentially, managers in the public sector are subject to the same nonmaximizing motives as private managers and are free from some of their constraints.

Public service employment would have some appeal if the government could train secondary workers and then release them into the private sector. But that is unlikely if workers are integrated into the civil service and not compartmentalized into a training program. Once these workers began to move up the civil service promotion ladders, which are dominated by seniority, most would find the entry rates at private firms unattractive. The labor force trends expected in the late 1970s and 1980s argue strongly against locking young workers into public service jobs that are created in an effort to expand the number of good jobs rather than the volume of public services.

In addition, government job creation of this sort may also create serious horizontal inequities. Since the government is a high-wage employer, the wages paid those workers chosen to participate would leapfrog over those of other secondary workers and even those of many in the large gray area that lies between the pure secondary and primary sectors. Welfare benefits and manpower training, on the other hand, move the poor upward relative to the nonpoor, but do not cause significant changes in the ordinal ranking of families in the income distribution. Under government creation of jobs 
an important political issue would arise about which secondary workers would earn the monopoly (wage) rents and which would remain in or near poverty. ${ }^{66}$

Finally, a serious unresolved question is whether the government can expand permanent public service jobs, without increasing inflation or decreasing private employment, when the economy is at full employment. ${ }^{67}$

The political outlook. Current public service programs have little in common with the dualist proposals: they are basically countercyclical; and they do not have the specific goal of hiring only secondary workers (rather than unemployed primary ones). Especially for programs run at the state and local levels, political considerations assure that secondary workers are rarely jumped in the income distribution past other workers. Hence, the "trickling down" of benefits to the lowest-skilled groups, a traditional feature of economic growth in the private sector, is a likely outcome of these programs. The dualist policy of moving secondary workers directly into primary jobs is more likely to result from adjudicated cases of discrimination than from current legislative programs. ${ }^{68}$

\section{OTHER POLICY OPTIONS}

If the prescriptions of legislating high wages and of permanent public service employment are rejected, the remaining policy tools for creating more good jobs are manpower training, which rests on the older analytical framework of human capital formation, and aggregate demand policies.

66. The government could circumvent this problem either by paying wages only slightly above those received in the secondary sector or by hiring workers from the gray areas between the prototype primary and dual sectors. Both of these remedies, however, fail to meet the original objectives of the dualists for public service employment oriented toward the poverty group. This objection precludes the guaranteed public employment proposals that offer job guarantees at a wage only slightly above the public assistance level. See, for example, Arnold H. Packer, "Categorical Public Employment Guarantees: A Proposed Solution to the Poverty Problem," in Studies in Public Welfare, Paper 9 (Pt. 1), pp. 68-127.

67. Most of the overall in-depth studies of public service employment have had pessimistic conclusions, especially for permanent public programs. Part of the problem is in project design, but important conceptual issues exist as well. See, for example, Laurence S. Seidman, "The Design of Federal Employment Programs: An Economic Analysis" (Ph.D. dissertation, University of California, Berkeley, 1974); and Alan Fechter, "Public Employment Programs: An Evaluative Study," Working Paper 963-41 (Urban Institute, September 1974).

68. See the Supreme Court ruling in Griggs v. Duke Power Co., and subsequent interpretations by lower courts. 
I omit discussion of antidiscrimination laws, since the only disagreements about them concern implementation.

Manpower training policies can be divided into two categories: those that are and those that are not tied to on-the-job training in private firms. The distinction then is based on whether the training program leads directly to placement in a "good" job. I would argue that subsidies and taxes to encourage firms to undertake specific and on-the-job training or to reduce turnover are justified on the grounds of external effects inherent in specific training and the social costs of turnover. Such a policy would be difficult to administer, and slow to work because it requires the adoption of new production techniques. Whatever its flaws, this policy seems analytically promising and avoids the ill side effects of legislating higher wages. Nor should policymakers be discouraged by the delay in the desired effects: structural problems, almost by definition, have no quick solution.

As far as the dualists are concerned, however, the policy of encouraging human (as well as physical) capital formation is not by itself satisfactory, since its income distribution effects do not assuredly favor the lower income classes. The growth of either human or physical capital could conceivably (depending upon the program and key parameters such as the elasticity of substitution among factors) increase the income dispersion by lowering the basic wage of untrained workers or increasing the share of property income. To the dualists, the narrowing of the income distribution is as important a goal as is the correction of structural problems. ${ }^{69}$ As mentioned above, however, some of them are prepared to accept "technological upgrading" as long as it is part of a policy package consisting of sharply higher minimum wages and measures geared to protect employment levels. In recommending extensive government planning and controls in the secondary sector, the dualists appear to view this sector as fitting the mold of J. K. Galbraith's "new industrial state."70

The second category of manpower training, the more traditional government-run programs, has been sharply criticized by the dualists as ineffective. In my view, this conclusion is subject to question. The dualist dichot-

69. Lester C. Thurow discusses this point in "Redistributional Aspects of Manpower Training Programs," in Ulman (ed.), Manpower Programs in the Policy Mix. He states "there is only one rationale left for current manpower programs. They must be designed to alter the distribution of earned income ... and not simply to raise the incomes of low-income workers" (pp. 84-85).

70. See, for example, Vietorisz, “\$3.50 Minimum Wage." 
omy of good and bad jobs hampers their evaluation of such programs. Manpower training does not achieve its aim in large jumps in short courses. It upgrades secondary workers a step at a time, so that they can fill better jobs in the secondary sector or jobs in the gray area between the primary and secondary sectors. ${ }^{71}$ The training programs should be expected to require considerable time, especially if it is necessary to overcome feedback effects. ${ }^{72}$ Also, manpower training is a complex business whose success depends crucially on how well the programs are constructed and fundedelements that have yet to be defined, despite some successes. Design itself, then, is a time-consuming process. This is also true for on-the-job training that aims at the creation of good jobs in the private sector-the "private school" equivalent of the "public school" of manpower training. Still, even given the complexities, I would argue that government-sponsored manpower training-especially on the job in the private sector-is preferable to the superficially quick "solution" offered by permanent public service employment and legislating higher wages.

Second, traditional aggregate demand policies may be more promising than the dual literature implies. Specifically, what the dualists view as the general inability (except at increasing rates of inflation) of monetary and fiscal policies to reach secondary workers directly may reflect instead the special increase in structural unemployment of secondary workers in the sixties. Where changing demographic patterns made demand management more difficult in those years, they may, in the next several years, be such as to enable aggregate demand policies to lower the overall unemployment rate.

Aggregate demand policies that recognize the changing characteristics of the labor market and set reasonable, noninflationary targets, are a crucial component of any policy aimed at eliminating the low-wage problem. Although demand policies may not be able to increase the real wages of many secondary workers directly, except at the cost of accelerating inflation, they should over time be able to do so indirectly. Economic growth and capital accumulation, associated with periods of stable and high demand, are the single most crucial ingredient in providing more good jobs.

71. The dualists' position on the ineffectiveness of manpower training is also based on their view that more good jobs will not be created in the private sector even if training programs create more good workers, and that secondary workers already have enough human capital to be employed in good jobs.

72. The feedback effects also suggest that policies be targeted at individuals before they enter the labor market. These policy options are not discussed in this paper. 
The near-term outlook on this front, however, is bleak. The current deep recession and the considerable outflow of real resources to the OPEC cartel will considerably hinder progress in reducing poverty.

Transfer payments are an alternative to job creation, to the extent that they are politically and socially acceptable as a substitute for wage income. Since nearly 40 percent of the low-income families have no wage earner and since the skill upgrading of the low-income workers will take time, transfer payments will continue to play an important part in antipoverty efforts. Although these payments have disincentive effects, such as increasing employment instability, they are indispensable. As noted above, government transfer programs have led to significant income gains for low-income families over the past decade. Demographic trends toward smaller families and fewer young families are likely to extend these gains over the long run, although the near-term trend is uncertain.

\section{Conclusions}

This paper yields several conclusions.

First, with respect to the primary sector, the dual literature has revived interest in the internal labor market. While the dualists interpret the internal labor market as operating largely without regard to efficiency, I suggest a different interpretation: it is best viewed as an efficient institutional response by firms to the basic market imperfections arising from the costs of information and of specific and on-the-job training. In this context, the dualist notion that primary firms fail to alter their job structure in response to the relative availability or price of labor with various levels of skill seems unlikely. Even an efficient internal labor market, however, will not solve externality problems, and the number of "good" jobs tends to be less than a social optimum. Hence, traditional issues such as the underinvestment in specific training by firms and workers arise as social problems that do require remedial action.

Second, a strict dualist division between primary and secondary sectors is not supported by the data. Mobility between the two sectors exists and the wage structure shows no evidence of bipolarization. Perhaps most important, however, is that although the institutional arrangements differ between structured (primary) and unstructured (secondary) labor markets, there is no evidence that the underlying process determining wages and 
behavior in the two sectors differs. The data do suggest the existence of segmented markets with imperfect mobility, arising from human capital constraints as well as the barriers that the dualists emphasize. The segmented-market approach, however, has a long and established position in neoclassical economics.

The dualist view of pervasive underemployment in the secondary sector is empirically unproven and, indeed, may not be testable. It remains an article of faith that workers in the secondary sector are potentially skilled enough to function in the primary sector (given the usual training costs) but are prevented by discrimination, imperfect information, and the failure of primary firms to adjust their job structure in response to the availability of good workers. Given the paucity of supporting evidence thus far, the dualist hypothesis does not provide a serious challenge to the human capital explanation. Nonetheless, the dualist model is a successful and innovative line of inquiry when evaluated as an empirical description of the workings of the lowest wage sectors in a traditional segmented model.

In addition, the dualists improve over most neoclassical models by introducing feedback effects into their model, although the implications of these effects are not fully integrated. The feedback hypothesis, an important concept in sociological and psychological models, views workers as altering behavioral patterns (that is, undergoing shifts in tastes or preferences) in response to external stimuli. For example, secondary workers adopt unstable work patterns as a consequence of distaste for low-wage, dead-end jobs. They then become unacceptable for employment in the primary sector, and, in a meaningful sense, inferior to primary workers-contrary to the dualist unemployment hypothesis that workers in the two sectors are largely indistinguishable in their skills, human capital, and the like.

Third, the dual evidence on unemployment of secondary workers has made an important contribution to understanding the unemployment mechanism. Secondary workers have an unstable attachment to particular jobs and to labor force participation in general. Low wages, job instability, and frequent short spells of unemployment provide the ingredients for the policy problem posed by the working poor. The dualists argue that this type of unemployment, with its associated poverty complications, is unresponsive to aggregate demand policies except at accelerating rates of inflation. But the dualist evidence is drawn from cross-section observations and ignores the changing demographic composition of unemployment, a serious omission for policy purposes. As a consequence of these changes, 
monetary and fiscal policy was hampered during the late 1960s and early 1970 s by a rise in the structural component of unemployment, but may face a more amenable situation within the next few years.

Fourth, the dualist solution to the joint problem of poverty and unemployment is to create more good jobs, mainly by legislating higher wages in the secondary sector or by establishing permanent public service jobs at primary wage scales for secondary workers. I argue that this approach amounts largely to the creation of more monopoly rent and will not solve the structural problems. The dualist policies geared to removing barriers through antidiscrimination laws, although certainly not novel, are more likely to have the desired effect. Furthermore, the general strategy of creating more good jobs appears promising. However, my recommended course would be oriented toward manpower training, either in the form of government-run training programs or by encouraging the private sector (through subsidies or taxes) to expand on-the-job training. The income distribution effects of the dual program should be achieved, if desired, through government transfer payments and not by legislating high wages.

Finally, the dual model does not provide an overall theory of the labor market. It does, however, stress factors, especially of an institutional nature, that have been ignored by most neoclassical economists. As such, the dual literature is a rich and provocative set of loosely connected empirical hypotheses about labor market behavior. I argue, however, that its novel empirical findings can be integrated into a traditional model and indeed are more easily understood in such a context. 


\section{Comments and Discussion}

R. A. Gordon: Wachter has presented a useful review of a substantial part of the recent, burgeoning literature on the dual labor market. The aim of the survey-which is not unsympathetic to a loose and flexible version of the dual hypothesis-is not only to review the literature but also to demonstrate that the findings that emerge from it can be fitted into a neoclassical framework. After all, Alfred Marshall-and Cairnes before himhad a theory of noncompeting groups.

Wachter deliberately refrains from considering any of the relevant literature from the radical school of economics. This is understandable, particularly given the limitations of time and space. The result, however, is inadequate attention to some important dimensions of the range of problems implied by the concept of a dual labor market-particularly how the relevant institutional environment has evolved and how its interaction with the factors stressed by orthodox economists creates the problems with which the literature on the dual labor market deals.

Wachter draws several significant conclusions from his analysis. First, he says, the dual theory does not provide an overall model of the labor market. This is certainly true. I also agree with the author, however, that the literature that he surveys does provide a "rich and provocative" set of hypotheses that need to be pursued.

Second, Wachter challenges the argument that internal labor markets are not dominated by efficiency considerations. In his words, the internal labor market is "an efficiency-oriented institutional response to the market forces generated by idiosyncratic jobs and the technology of on-the-job training." This statement - rather a mouthful-covers a lot of ground. I am prepared to agree that "efficiency considerations" (if we can settle on a definition of that term) do affect job design, promotion criteria, and in- 
ternal wage structures. But what are the institutional constraints that govern the manner in which these efficiency considerations are applied? How did these constraints evolve? And to what extent are they subject to change?

In my own work, I have been impressed by the relatively low unemployment rates in some sectors of the primary labor market and by the need to redesign jobs and to alter promotion and seniority patterns to provide more good jobs for those now on the fringes of the primary labor market. The obstacles to doing so are not the "inefficiency," in a loose sense, of employers, but rather inertia, lack of information, and a wide variety of institutional constraints.

Wachter concludes that the data do not support a strict dualist division between primary and secondary sectors. Strictly speaking, this is certainly true. On the other hand, it is also true that the total labor market is divided into sectors, among which mobility is restricted. The labor force can be classified in a variety of ways, depending on which of its dimensions are to be emphasized. Demographic characteristics-age, sex, and color-have been the focus of the recent literature. If these dimensions are used, it is perhaps not inaccurate to refer to wage distributions that have distinctly different central tendencies-but that do overlap.

What bothers me most about the strict dual market approach is its tendency to lump nonwhites, teenagers, and women into one presumably homogeneous labor force, to which the same set of institutional constraints applies. All three of these overlapping segments of the labor force undeniably suffer from one or another type of discrimination (whether conscious or unconscious); and none of them can become white, prime-age males (except for white teenagers in the customary course of time). But each of these groups enters the labor market with different handicaps of different origins; the distribution of human capital is different for each, and so is the distribution of employment by occupation and industry.

According to Wachter, advocates of the dual market hypothesis do not integrate feedback effects into their models. They do not, in other words, take adequate account of the extent to which and the ways in which the conditions of work impair the ability of secondary workers to qualify for primary jobs. The truth of this observation depends on the author one is citing.

My main point in this connection is that Wachter does not go far enough. This problem of "institutional conditioning" extends far beyond 
the conditions of work in the secondary job market-to family background and neighborhood, housing conditions, the cultural environment during the preschool and school years, and so on. And here again, the relevant secondary workers do not form a homogeneous group. This "institutional conditioning" is far different, for example, for black teenagers in urban ghettoes than for middle-class married white women reentering the labor force.

Another conclusion of Wachter's analysis is that what he terms "the structural component of unemployment" will decline in the rest of the seventies, presumably and primarily because the teenagers of the recent past and the present will be becoming prime-age adults. I agree with that prediction, and previously stated it, as Wachter notes. But he does not mention that the percentage of white males age 35-64 in the labor force will continue to decline through the rest of the decade. What effect will that have on wage inflation and on wage and unemployment differentials (particularly with respect to young adult males) during this period?

Finally, in the area of policy solutions, Wachter emphasizes the need for manpower training - both on-the-job training programs subsidized by the government and programs administered directly by the government. $\mathrm{He}$ has little to say about the mixed results of the training programs of the last decade-about recent experience with the JOBS program or about the reluctance of large-scale employers to endure the paper work involved in applying for federal subsidies. Given the external pressures that they have felt, they have preferred to engage in their own "outreach" programs, to "cream off" the top, and then to forget about it when labor market conditions eased. Furthermore, Wachter makes no mention of the possible results of the 1973 legislation that shifts the responsibility for training programs to state and local governments.

One final comment. Wachter is not sympathetic to public service employment as even a partial solution to the problem created by the existence of a secondary labor market. "Leakages"- the substitution of federal subsidies for employees at the state and local level who otherwise would be financed out of state and local revenues-are a problem that cannot be ignored. But, with adequate legislative and administrative safeguards, it can be controlled. Perhaps for no better reason than early involvement in the cause, I continue to support what I have termed a "two-tier" program of public service employment-a permanent, underlying tier of jobs for the structurally underprivileged and, in addition, a "triggered" 
cyclical program to deal with the rising unemployment that emerges in recessions like the present one.

Michael J. Piore: I have had considerable trouble in attempting to respond to Michael Wachter's paper. My problems spring, I think, in large measure from the paper itself. Essentially, it undertakes a threefold task: to identify a common core in the writings about dual labor markets; to distinguish the points at which that common core conflicts with neoclassical theory; and finally, to assay and if possible resolve that conflict. Given the disparate writings on dualism and (the rhetoric notwithstanding) the implicit nature of much of the conflict with orthodox theory, Wachter has set himself no easy task, and it is not surprising that the paper fails. Nonetheless, I think Wachter is basically right in his presumption of a set of common themes in the "dualist" work and of their fundamental conflict with orthodox professional thinking. Those themes, moreover, appear very disturbing to neoclassical labor economics-much more disturbing, I must admit candidly, than the quality of the work seems by itself to warrant. And it seems to me that Wachter's paper, whatever its failings in articulating the conflict, comes closer to catching the spirit of the underlying issues than most contributions to this debate. For these reasons, I shall respond to what I think the paper is trying to say rather than to precisely what it does say. I want to make three points: one about evidence, one about theory, and one about policy. In order not to confuse the issue further, I will speak in the first person, although on much of this I do not necessarily speak for myself alone.

On evidence: The first point I want to discuss is the interpretation of the efforts to test the dual hypothesis econometrically. The analytical constructs of the dual labor market and the internal labor market represent attempts to capture the conception that the actors in the labor market themselves have of the world in which they operate. These concepts derive from open-ended interviews with the actors and from the experience of the researchers themselves in various projects and programs. Many of the features of the internal labor market, and some of the dual labor market, are also written in legislation, court opinions, collective bargaining agreements, arbitration awards, and the like. All of this is evidence, if not the kind normally admitted in the court of economics. For those of us who have collected it, and remain immersed in it, it is overwhelming evidence. And 
I, for one, am not about to dismiss any of the constructs simply because econometric evidence fails to support it.

I do not want to ignore the econometric evidence; but I am much more likely to infer from that evidence that $I$ got the structure wrong or that they got me wrong than that the labor market structures I have talked about have no reality and do not require an explanation. Often the econometric evidence is made the central issue in debates on this area (although it is by no means unambiguous taken even on its own terms). It is also raised in Wachter's paper but it is not, I think, really an issue between us. I don't think we would have any real difficulty agreeing on what exists and what needs to be explained. Our disagreement is really theoretical.

On theory: The theoretical issue is a subtle one and it is fundamental. I do not know whether I can present it clearly, but I am going to try. The issue is one of where and how one looks for explanations of the structures that the dual labor market and the internal labor market contain. Wachter has been looking for these explanations in "information" and "training." I have been looking for them, in addition, in the processes through which technology develops and changes and in the interaction between economic processes and worker preferences (or tastes). The thrust of my approach is to make both technology and tastes integral parts of the economic process and to understand labor market structure as the product of that integration.

Part of our differences can be traced to the difference between "information" and "training," on the one hand, and "technology" and "tastes," on the other, within the neoclassical framework. Neoclassical theory is essentially a story about a world in which technology and tastes are given. As soon as one tries to build into an economic model a process that generates technology and tastes, one goes beyond neoclassical theory. That story is then no longer central to the understanding of economic activity, and, in the sense that theoretical disputes basically involve what should be made "central," a fundamental antagonism develops. Such an antagonism is manifested by Wachter's concern with efficiency. His text, however, is somewhat misleading on this score. I am not arguing that the firm operates inefficiently and certainly not that management fails to minimize cost. However, when tastes and technology are made endogenous to the economy, the term "efficiency," as it is understood in neoclassical theory, loses its meaning. "Information" and "training" do not pose the same problems 
for the neoclassical model and, in that sense, the labor market structure can be efficient in Wachter's view of the world in a way that it cannot be in mine.

Our disagreements, however, are really more fundamental than this, for they concern not only where one looks for an explanation but how one looks. Wachter's approach has been to treat "information" and "training" essentially as commodities with a carefully limited number of peculiar properties. These commodities are then introduced into the neoclassical model, and the model adjusted to their peculiarities. With luck (or proper selection of the properties of the commodities), the essential orthodox model survives. In this, Wachter is following the thrust of contemporary economic theory, not only at Chicago but at more mathematically oriented schools as well. If there is a difference, it is that the institutions he is seeking to explain have eluded the tight mathematical specification that would enable him to proceed at the abstract level of most contemporary theory.

I sympathize with the efforts of Wachter, and of the profession generally, to salvage neoclassical theory in this way (we "dualists" are more aware of the intellectual mess we have made for ourselves by departing from the orthodox framework than our colleagues recognize). But I think the effort is misplaced; particularly in labor market theory, whose motivation springs from serious policy concerns, it involves a fundamental misunderstanding of the nature of neoclassical theory and its relation to policy. Basically, neoclassical theory is a good story. Even though technology and tastes are given, it is a very rich story, and it has been a particularly rich source of policy for the control of economic systems. Also, the story has now been so refined that it can often be written in tight mathematical notation. But the richness of the story is not conveyed by its mathematical formulation, and almost all the policy insights of neoclassical theory are drawn from the story, not the equations.

To meet the challenge posed by the internal labor market and the dual labor market-more particularly by the concerns about income distribution and social mobility that led to the formulation of these constructsone must be armed with a story that is as rich as the neoclassical one. And the attempt to define information and training as mathematically tractable commodities that fit readily into the neoclassical equations is not producing a story about information and training rich enough to serve as the fountainhead of policy. It does not even offer criteria by which to judge whether the properties ascribed to these "commodities" in order to introduce them 
into neoclassical models make any sense. Moreover, in any complete story about information and training, I believe that both must be viewed as cognitive processes. These processes are, to some extent, the same as those involved in the generation of technology and tastes, and they cannot be made to fit into a model in which technology and tastes are exogenous. My argument, in its boldest form, is that the story that will support the model that Wachter is trying to construct on the basis of information and training implies a story about technology and tastes as well which is inconsistent with neoclassical theory. The technology-and-tastes story is needed for policy purposes in any case, and once it is constructed, it undermines Wachter's approach, even as a theoretical exercise. Of course, to offer a really compelling argument, I should be able to tell you that story. And I can't. But since the dualist debate has so often bogged down in a host of irrelevant issues, which Wachter's paper has avoided, I do think it is very important to emphasize that the "story" is the fundamental issue.

On policy: In the area of policy, I believe that the paper completely misses the critical consideration in the secondary sector in the coming decades: illegal immigration. Virtually unnoticed, illegal aliens have become a factor of tremendous-and still explosively growing-importance. Estimates made by the Immigration and Naturalization Service (INS) put the illegal alien population between 4 million and 12 million in 1974, roughly similar to the number of legal aliens in Western European economies (whose position has been compared to that of our black population). The rate of increase is suggested by the number of apprehensions by the INS: about 500,000 in 1972, 655,000 in 1973, and 800,000 in 1974. The growth in this population is concentrated in urban industrial centers in the Northeast, the Midwest, and California.

Illegal aliens constitute a labor force in perpetual fear of disclosure. This fear exposes them to the worst kind of exploitation, and creates the opportunity for an underground labor market. The economic incentives for such a labor market are large. In it, an employer can escape minimum wage legislation, legal health and safety standards, social security taxes, unemployment insurance, workman's compensation, and income tax withholding. The deterrents to such a labor market are the heavy penalties that violations of these statutes carry and, to a certain degree, social custom. At present, the employer who uses alien labor incurs no legal sanction. The thrust of most policy proposals, however, is to make the employer responsible for the status of his workers. Once such proposals are implemented, 
the balance of penalties will change and I see a strong likelihood that employers, having already violated the law by hiring aliens, will violate other laws to retain them and to make the maximum profit out of employing them.

This discussion suggests that the concerns of the dualists with eliminating the secondary sector through large increases in the minimum wage, public service jobs, and the like are misplaced. The battle of the next decade will be defensive: to preserve minimal standards of wages, working conditions, and social insurance, and to prevent the secondary sector from reverting to the conditions of the late nineteenth and early twentieth century.

But, in a certain sense, the phenomenon of illegal immigration does seem to me to support the analysis that gave rise to such dualist policy proposals. For analytical purposes, the great mystery of illegal immigration is not why it is occurring now but why it failed to occur two or three decades earlier, when the disparities of income between the United States and Latin America (from which most of the illegal aliens are coming) were, if anything, larger. The answer appears to be that the new immigration is a response to a vacuum in urban industrial labor markets created by the refusal of black workers, whose parents came from the rural South, to accept secondary jobs, and the exhaustion of rural labor reserves from which a new, more "docile" black labor force might be drawn. The movement of the bumper postwar baby crop out of adolescence, which Wachter notes, is aggravating this shortage. The economy is behaving, in other words, as if the job and wage structure were fixed, and the labor force, one way or another-in this case through immigration-gets adjusted to it. The floor on the job and wage structure appears to be established by law, and if that legal floor had been higher, as the dualists wanted to make it, jobs would probably have been better. I tend to doubt that they would have been primary jobs (for reasons that require a much more extended discussion than I can undertake here). In any case, this evidence certainly does not fit an orthodox model in which labor supply is a real constraint and legal intervention simply creates unemployment. Indeed, in certain respects, it is much more consistent with a Marxian world that will have its subproletariat-if not drawn from blacks or youth, then from abroad.

Robert E. Hall: Michael Wachter has taken on the difficult task of appraising the rather loosely organized body of thought on segmentation of the labor market. A major theme of his critique is that the economics of 
dualism is really just standard "neoclassical" economics. I think he overstates the success of standard economic theory in comprehending three phenomena of direct concern to the dualists: discrimination, bilateral monopoly, and unemployment. Discrimination is a pervasive and welldocumented feature of labor markets and is central to the dualists' explanation of segmentation. No neoclassical theory satisfactorily explains the survival of discrimination in the presence of powerful economic forces that should undermine it.

Bilateral monopoly characterizes the relation of workers and employers whenever there is human capital specific to the employer. Standard economic theory has little to say about the division of the return to specific capital between workers and employers. I think Wachter is correct, however, in stressing that the institutions of the internal labor market deal with bilateral monopoly in an economically efficient way and are less arbitrary than the dualists would have us believe.

Finally, only recently have standard economic theorists come to grips with unemployment. Their success in explaining the facts of unemployment-many of them pointed out by the dualists-is still far from complete.

Wachter discusses the empirical evidence for segmentation only briefly. He concludes, I think correctly, that segmentation exists in the sense that there are large, systematic, unexplained differences in earnings among different groups of workers, but that no literal duality is apparent in the data. To this static view I would add that recent studies of mobility between jobs give no support to the dualists' hypothesis that secondary workers become trapped in bad jobs. Among young workers, movement from bad to good jobs is surprisingly common. In this respect, I think Wachter takes too seriously the dualists' stereotype of good jobs filled entirely from the internal labor market. The data on mobility show frequent movements into good jobs well above entry levels via the external labor market.

I disagree with two of Wachter's conclusions about government intervention in the labor market. First, he finds it inappropriate to compel or induce the hiring of secondary workers into primary jobs, where the primary jobs pay high wages because of the monopoly power of those holding them. He argues that such an expansion of employment would only add to monopoly power. Of course, this is true in terms of the number of workers protected by monopoly, but the appropriate measure of the inequity and inefficiency of monopoly is the wage differential between good and 
bad jobs, which would narrow. Second, he favors training programs as the major tool for raising the income of low-wage workers. Evidence accumulated since my pessimistic paper (BPEA, 3:1971), which evaluated manpower programs that operate within labor markets with existing institutions, has not convinced me that I was wrong. There is a shortage of good jobs, and merely equipping workers to hold good jobs is not enough.

Michael L. Wachter: I agree with Michael Piore that the endogeneity of tastes and technology is the major issue on which dualist and neoclassical models diverge. (This is an interesting agreement between us, since to other dualists, other issues that I raise in the paper seem to be central.) I also agree with Piore that neoclassical economics is to be faulted for neglecting tastes and technology. I disagree, however, that the dualist "story about technology and tastes ... is inconsistent with neoclassical theory." This, in part, is a definitional issue; to Piore, endogenous tastes and technology seem to be defined as nonneoclassical. Since Piore admits that the dualist work in this area is just beginning, there is no reason to assume that its ultimate findings will be incompatible with the general thrust of orthodox economic theory. In a sense, the results may be able to fill the "empty boxes" of taste and technology in the neoclassical model. ${ }^{1}$

Specifically, although Piore and others have made some useful progress in understanding tastes and technology, important empirical and theoretical questions remain unanswered. For example, what is the dualist position or evidence on the culture-of-poverty hypothesis? How reversible or irreversible are feedback effects in the poverty population? Are these effects developed largely before or after entry into the labor market? Are they created before or after entry into elementary school? With respect to technology, what are its endogenous determinants? Lacking empirical answers to these questions, dualist policy recommendations would have to be viewed as highly preliminary.

My impression is that Piore draws too sharp a distinction between my "information and training" approach and his "tastes and technology." Although I use the former concepts to discuss a broad range of issues, the endogeneity of tastes and technology is related to issues about information and training.

1. For a neoclassical treatment of endogenous taste change, see Robert A. Pollak, "Habit Formation and Dynamic Demand Functions," Journal of Political Economy, Vol. 78 (July/August 1970), Pt. 1, pp. 745-63. 
I am very sympathetic to Piore's concerns that attempts to build mathematical rigor into neoclassical models often leads to highly generalized models with untestable or uninteresting hypotheses. I am also concerned, however, that the desire of the dualists to create a rich story has led them to an approach that may be too descriptive to suggest testable hypotheses.

I should also like to respond briefly to Robert Hall's comments. I agree with him that manpower policies have not generally been successful to date; but I am still hopeful that, with better design and administration, such training, especially if done on the job, can become more successful. In addition, as my paper makes clear, I agree that there is a shortage of good jobs. It does not follow, however, that "equipping workers to hold good jobs is not enough." For I see a shortage of good workers as well as good jobs, and believe that, if manpower training programs are successful in creating "good workers," the labor market will adjust to the change in relative factor availability.

\section{General Discussion}

Marina Whitman started an extended discussion by asking for a definition of a "good job" in dual theory: Michael Piore listed several characteristics: high wages, good working conditions, opportunities for advancement, a structured relationship with supervisors-all of which bear on the stability of the job. At Stephen Magee's suggestion, Piore conceded that a sizable endowment of human capital might also belong on the list.

The list reinforced Whitman's belief that a good job is defined by its rewards, and not by its function; thus, garbage collecting could be a good job. Piore suggested that, if the wage of a job is high, the other favorable characteristics would ordinarily follow, as employers and employees adjust to the pay. Wachter and Robert Dorfman did not believe that Piore's job characteristics would neatly divide jobs into "good" and "bad." Dorfman pointed to two examples of high-wage jobs with bad-job characteristics: longshoremen with unstable work, and auto production workers who complain of bad working conditions. Dorfman also wondered whether some allegedly secondary jobs were not really "exploratory" jobs for young people who outgrew them with maturity.

Arthur Okun attributed many aspects of the partitioned labor market to the fact that labor, unlike machines, cannot be bought outright or even on 
a long-term contract. A firm will not invest in a worker to the socially optimum extent because it cannot be sure of capturing the benefits of the investment. Given this market failure, employers have two basic options: (1) to invest in workers and seek to develop lasting attachments through tenure, promotion, pensions, and the like; or (2) not to train workers and thus to tolerate the high turnover of "bad jobs." Piore said Okun's approach might explain the existence of different labor markets, but not how the different markets operate. Wachter felt that the dual theory does not provide this explanation either.

Charles Holt said that most empirical studies support a segmented labor market, but not a simple, two-part market. Edward Erickson reported on evidence that the high wages of concentrated industries could be explained, at least in part, by the high capital intensity of production in these industries and the complementarity of skill and capital intensity, without appealing to either nonneoclassical or monopoly elements.

There was some disagreement about the role of labor unions in the dual labor market. Hendrik Houthakker felt that some scarcity of good jobs was attributable to labor unions and some to monopolistic restrictions (including those in regulated industries like trucking) that operate directly on product markets. Robert Hall reiterated his point that opening up union jobs reduces the monopoly power of particular unions. Wachter questioned the relevance of Hall's point in an economy in which many workers cannot forcibly be organized into strong unions due to the nature of the relevant product and labor markets. Piore emphasized that labor unions need to be considered a result of the system (and to be encompassed by an endogenous theory) as well as a force operating on the system.

Stephen Marston discussed the role of income maintenance programs, such as unemployment insurance and welfare, in dual labor theories. Dualists cite these programs in explaining why unemployment can coexist with numerous vacancies in jobs that are considered bad. Yet the dualists do not discuss the possibility of reforming the programs of income maintenance in order to increase attachment in these jobs and reduce unemployment.

Dorfman thought the discussion of discrimination in dual theory casts the issue in a narrowly American context. He and Franco Modigliani wondered whether the same patterns exist in countries with a much more homogeneous labor force, like Sweden. Information along these lines might throw light on the influence of discrimination in U.S. labor markets. Unlike Hall, Holt and Wachter were not willing to write off manpower 
programs. They insisted that the programs that have been tried have been crude and do not necessarily illuminate the true possibilities of training and job matching. Holt suggested, for example, that the Employment Service's current information on jobs is very "thin," stressing detailed occupational distinctions but omitting other key dimensions. Both Wachter and Erickson cited studies that showed some net benefits from particular manpower training programs. 